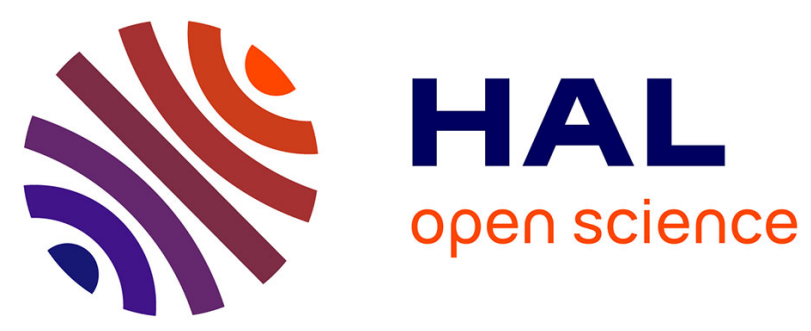

\title{
Localized Afterslip at Geometrical Complexities Revealed by InSAR After the 2016 Central Italy Seismic Sequence
}

Lea Pousse-Beltran, Anne Socquet, Lucilla Benedetti, Marie-Pierre Doin, Magali Rizza, Nicola d'Agostino

\section{To cite this version:}

Lea Pousse-Beltran, Anne Socquet, Lucilla Benedetti, Marie-Pierre Doin, Magali Rizza, et al.. Localized Afterslip at Geometrical Complexities Revealed by InSAR After the 2016 Central Italy Seismic Sequence. Journal of Geophysical Research: Solid Earth, 2020, 125 (11), 10.1029/2019JB019065. hal-03027096

\section{HAL Id: hal-03027096 https://hal.science/hal-03027096}

Submitted on 27 Nov 2020

HAL is a multi-disciplinary open access archive for the deposit and dissemination of scientific research documents, whether they are published or not. The documents may come from teaching and research institutions in France or abroad, or from public or private research centers.
L'archive ouverte pluridisciplinaire HAL, est destinée au dépôt et à la diffusion de documents scientifiques de niveau recherche, publiés ou non, émanant des établissements d'enseignement et de recherche français ou étrangers, des laboratoires publics ou privés. 
2 Title:

3 Localized afterslip at geometrical complexities revealed by InSAR after the 2016 Central Italy

4 seismic sequence

5 Authors:

6 Léa Pousse-Beltran ${ }^{1}$, Anne Socquet ${ }^{2}$, Lucilla Benedetti ${ }^{1}$, Marie-Pierre Doin ${ }^{2}$, Magali Rizza ${ }^{1}$,

7 Nicola D'Agostino ${ }^{3}$

8

$9{ }^{1}$ Aix Marseille Université, CNRS, IRD, Collège de France, CEREGE, Aix-en-Provence, France

102 Université Grenoble-Alpes, Université de Savoie Mont-Blanc, CNRS, IRD, IFSTTAR, ISTerre,

1138000 Grenoble, France

$12{ }^{3}$ Istituto Nazionale di Geofisica e Vulcanologia (INGV), Centro Nazionale Terremoti, via di Vigna

13 Murata 605, 00143, Rome, Italy

14

15

16 Email list:

17 Léa Pousse-Beltran: pousse@cerege.fr

18 Anne Socquet : anne.socquet@univ-grenoble-alpes.fr

19 Lucilla Benedetti : $\underline{\text { benedetti@cerege.fr }}$

20 Marie-Pierre Doin : marie-pierre.doin@univ-grenoble-alpes.fr

21 Magali Rizza : rizza@cerege.fr

22 Nicola D’Agostino : nicola.dagostino@ingv.it

23

24 
25 Keywords:

26 - Postseismic

$27 \quad-\quad$ InSAR time-series

28 - 2016-2017 Amatrice-Norcia Seismic Sequence

29 - Geometrical complexity

30

31 Key points:

32

- We monitor pre and post-seismic deformation of the 2016 seismic sequence using twoyear InSAR time-series

34 - Centimetre scale post-seismic surface displacements are detected after October 30, 2016 Mw 6.5 mainshock (Norcia earthquake)

36 - Localized shallow afterslip occurred at structural complexity that may have hindered the propagation of seismic ruptures

38

39 


\section{Abstract :}

The Mw 6.5 Norcia earthquake occurred on October 30, 2016, along the Mt Vettore

42 fault (Central Apennines, Italy), it was the largest earthquake of the 2016-2017 seismic

43 sequence that started two months earlier with the Mw 6.0 Amatrice earthquake (August, 24).

44 To detect potential slow slip during the sequence, we produced Interferometric Synthetic

45 Aperture Radar (InSAR) time-series using 12 to 6-day repeat cycles of Sentinel-1A/1B images.

46 Time-series indicates that centimetre-scale surface displacements took place during the 10

47 weeks following the Norcia earthquake. Two areas of subsidence are detected: one in the

48 Castelluccio basin (hanging wall of the Mt Vettore fault), and one in the southern extent of the

49 Norcia earthquake surface rupture, near an inherited thrust. Poroelastic and viscoelastic

50 models are unable to explain these displacements. In the Castelluccio basin, the displacement

51 reaches $13.2 \pm 1.4 \mathrm{~mm}$ in the ascending line of sight (LOS) on January 06,2017 . South of the

52 Norcia earthquake surface rupture (a zone between the Norcia and Amatrice earthquakes),

53 the post-seismic surface displacements affect a smaller area, but reach $35.5 \pm 1.7 \mathrm{~mm}$ in

54 ascending LOS by January 2017 and follow a logarithmic temporal decay consistent with post-

55 seismic afterslip. Our analysis suggests that the structurally complex area located south of the

56 Norcia rupture (30 October) is characterized by a conditionally stable frictional regime. This

57 geometrical and frictional barrier likely halted rupture propagation during the Amatrice

58 (August 24) and Norcia (October 30) earthquakes at shallow depth (<3-4 km). 
Monitoring the spatial and temporal variations of the slip on a fault enables researchers to better assess stress build-up on seismic asperities and slip released during seismic cycle (Avouac, 2015; Bürgmann, 2018; Chen \& Bürgmann, 2017; Harris, 2017). In the rate and state formulation, rupture propagation can be hindered by rate-strengthening sections of a fault, which tend to slip via creep rather than in seismic rupture (e.g., H. Perfettini et al., 2010; Hirose et al., 2010). Such barriers are also often associated with structural complexities - such as a change of strike, secondary faulting or interaction with inherited faults (e.g., King \& Nabelek, 1985; King, 1986; Wesnousky, 1988). These structural complexities can act as a geometrical barrier, and are characterized by an increased equivalent strength (Nielsen \& Knopoff, 1998). Locating aseismic slip on the fault and comparing these locations with those of seismic slip and fault segmentation is of pivotal importance to better characterize the frictional behavior of a fault system and its relation with structural complexities.

A notable seismic sequence occurred in the Central Apennines (Italy) in 2016-2017 74 (Chiarabba et al., 2018; Perouse et al., 2018; Cheloni et al., 2017; Huang et al., 2017; Cirella et al., 2018; Civico et al., 2018; Scognamiglio et al., 2018; Ragon et al., 2019), with four main events: the $24^{\text {th }}$ August $2016 \mathrm{Mw} 6.0$ Amatrice event, the $26^{\text {th }}$ October $2016 \mathrm{Mw} 5.9$ Visso event, the 30 $30^{\text {th }}$ October $2016 \mathrm{Mw} 6.5$ Norcia event, and the $18^{\text {th }}$ January $2017 \mathrm{Mw} 5.5$ Campotosto event (Figure 1 and Table S1). This seismic sequence ruptured the complex Mt Vettore fault system (in red in Figure 1) (Pizzi et al., 2017; Porreca et al., 2018; Villani, Pucci, et al., 2018), and the adjacent Amatrice-Campotosto fault (in orange in Figure 1). During the Norcia earthquake, the rupturing of an antithetic fault on the opposite side of the Castelluccio basin seems necessary to fit geodetic data and is supported by alignments of relocated aftershocks (Chiaraluce et al., 2017; Walters et al., 2018; Cheloni et al., 2019). In addition, the role of an inherited west-dipping thrust called OAS (Olevano-Antrodoco-Sibillini thrust) in the Norcia earthquake coseismic rupture geometry has been widely discussed. While some studies suggested that only the Mt Vettore fault system was activated (Chiaraluce et al., 2017; Liu et al., 2017; Papadopoulos et al., 2017; Pavlides et al., 2017; Pizzi et al., 2017; Wang et al., 2018; Xu et al., 2017), others suggested that also the OAS thrust ruptured as a reactivated high-angle normal fault during the event, as suggested by geodetic and seismological observations

90 (Cheloni et al., 2017; Scognamiglio et al., 2018; Walters et al., 2018). Although the reactivation 91 of the thrust is not clearly demonstrated (Cheloni et al., 2019), the OAS appears to have played 
a role in the aftershock distribution (Chiarabba et al., 2018; Chiaraluce et al., 2017; Pizzi et al., 2017). The earthquakes of the 2016 sequence appear to have nucleated near crosscutting

94 structures that seem to have been loaded by previous ruptures in the sequence (Chiaraluce et al., 2017; Pino et al., 2019). This seismic sequence is thus an excellent case study to better understand the link between structural segmentation, aseismic slip and frictional properties that might control this rupture propagation.

Post-seismic processes during this sequence have been observed in the seismicity (e.g., Albano et al., 2018; Tung \& Masterlark, 2018), but no aseismic slip has been detected with geodetic data so far. Using Interferometric Synthetic Aperture Radar (InSAR) time-series from Sentinel-1 data, we document a small but significant post-seismic deformation transient that we find is best explained by aseismic slip on faults associated with this sequence. Surface displacements are presented and analysed. We also explore simple modelling schemes that provide a framework for our interpretation and discussion.

\section{Geological setting}

The Central Apennines were affected by an extensional phase during the Jurassic, followed by a compressive phase during the Neogene (e.g., Calamita et al., 2011). The OAS (Olevano-Antrodoco-Sibillini thrust) is one the main thrusts resulting from the Neogene compressive phase (Calamita et al., 1994) and has been interpreted as a transpressive ramp (Di Domenica et al., 2012). In the area affected by the 2016-2017 seismic sequence, the OAS thrust is expressed by parallel splays associated with fault-bend folds characteristic of structural ramps (Calamita et al., 2012) (Figure 1). The ongoing ENE oriented extension of 2 to $4 \mathrm{~mm} / \mathrm{yr}$ (D’Agostino, 2014; Carafa \& Bird, 2016; Devoti et al., 2017), which probably began in the Early Pleistocene (e.g., Galadini \& Galli, 2000), is currently accommodated through normal fault systems such as the Monte Vettore fault system that hosted the 2016-2017 seismic sequence.

\section{Surface displacements during the seismic sequence}

\subsection{InSAR processing}

Synthetic radar interferometry (InSAR) is now systematically used to constrain deformation fields (Elliott, Walters, et al., 2016) and can document centimetre to millimetre scale slow aseismic ground deformation using an adapted processing chain (Hussain et al., 
2018; Aslan et al., 2019). We used C band (5.5 cm wavelength) images from Sentinel-1A/B images (Figure 1-A) spanning almost two years (July 28, 2015, to June 11, 2017) for the ascending track (A117, subswath IW3). To confirm the main observations made on the ascending track, we processed descending track (D22, subswaths IW2 and IW3) images from October 26, 2016 to February 11, 2017. SAR images were processed in VV polarization. We used the NSBAS processing chain (Doin et al., 2011, 2015) modified for Sentinel data by Grandin (2015) to generate differential interferograms. The interferogram network, and examples of unfiltered and uncorrected interferograms, are provided in Figures S1 and S2. The Shuttle Radar Topography Mission digital elevation model (DEM) at 3 arc sec resolution (Rabus et al., 2003), resampled at $45 \mathrm{~m}$ resolution, has been used to accurately coregister the focused SAR images and to correct interferograms from the topographic contribution to the interferometric phase. We removed a ramp in range and in azimuth for each interferogram using the methodology of Cavalié et al., (2007) included in NSBAS. We de-noised the interferograms before unwrapping using collinearity, a criterion to characterize at each pixel the local spatial variability of the phase (Pinel-Puysségur et al., 2012). The collinearity was used to adapt the strength of the filter. We filtered for a window of 12 pixels $(400 \mathrm{~m}$ in range and 700m in azimuth); the filter is described in Doin et al. (2011) and is based on the collinearity value which weights the complex phase in a sliding window. For the filter we had the option of adapting the weighting of the phase within windows of different sizes. This size adaptation depends on the collinearity within the windows. Unwrapping was performed in 2D with the NSBAS chain (Grandin et al., 2012; Doin et al., 2015). After unwrapping, to account for errors associated with stratified troposphere, we removed a quadratic cross-function of elevation $(z)$ and azimuth to ramps in azimuth $(y)$ and in range $(x)$ estimation following the function $a x+b y+c+e z+f z \times a z+g \times(z \times a z)^{2}$ using a least-square approach (Daout et al., 2019). Time-series were then calculated following the NSBAS method (Doin et al., 2011; Daout et al., 2016) using an approach based on the Small Baseline Subset time-series Analysis (SBAS) of López-Quiroz et al., (2009)'s algorithm. The smoothing of the pixel time-series is performed by minimizing the Laplacian of the temporal evolution of the deformation (Cavalié et al., 2007). The final pixel size is $62 \mathrm{~m}$ in azimuth and $37 \mathrm{~m}$ in range. We removed pixels with an RMS value greater than 0.7. For the ascending track, we build a time series spanning the 2 years (from 28/07/2015 to 11/06/2017) (Figure S1 and see missing links in the time series in Figure S3). For this complete 2-year time-series, we encounter problems in unwrapping the co-seismic interferograms due 
to the large deformation with respect to the Sentinel wavelength in near field (aliasing). Fringes are too close in space and cannot be unwrapped. At pixels that are incoherent in the co-seismic interferogram (i.e. in near field), this causes gaps in the complete ( $2 \mathrm{yrs}$ ) time-series spanning the main earthquakes (Norcia, Amatrice and Campotosto earthquakes) (Figure S3), or lead to an underestimation of the coseismic displacement (brown circles in Figure 2-D). In addition, we also build three time-series in between earthquakes in order to avoid possible bias: before the $24^{\text {th }}$ August (Amatrice earthquake), between $27^{\text {th }}$ August and $26^{\text {th }}$ October (between the Amatrice and Visso earthquake), and after the $30^{\text {th }}$ October (Norcia earthquake). We excluded the SAR data from January 18, 2017, which produced noised interferograms. For the descending track, we build two time-series: between $27^{\text {th }}$ August and $26^{\text {th }}$ October (Visso earthquake), and after the $30^{\text {th }}$ October (Norcia earthquake).

\subsection{Time-series results and description of the main features}

\subsubsection{Ascending Track}

The ascending time-series built before the seismic sequence (from July $28^{\text {th }} 2015$ to August $21^{\text {th }} 2016$ ) does not show significant nor localized surface displacements along the main faults (Figure S4-A,B). After October $30^{\text {th }}$, the (post-Norcia) time-series shows centimetre-scale displacements going away from the satellite in the LOS direction in three areas (Figure 2-B):

- South of Amatrice: In the area affected by the Campotosto earthquake (January $18^{\text {th }}, 2017 \mathrm{Mw}$ 5.0 -5.5 EQ) the ground surface moved away from the satellite by more than $60 \mathrm{~mm}$ in LOS (Figure 2-B). This coseismic displacement results in a step function in the time series, and can therefore be easily separated from any gradual post-seismic deformation.

- Near Arquata del Tronto: At the southern extremity of surface rupture of the $\mathrm{Mw}$ 6.5 October $30^{\text {th }}$ Norcia earthquake (red faults in Figure 2), surface displacements are detected over an area of $\sim 12 \mathrm{~km}^{2}$, and follow logarithmic evolution (in Figure 2-D and Figure 3-A see time-series at point 1 where the cumulative post-Norcia displacements in LOS on January 06, 2017 is in average $35.5 \pm 1.7 \mathrm{~mm}$ and reach $50.5 \pm 2.1 \mathrm{~mm}$ on 30 April 2017)

- Castelluccio Basin: On the hanging wall of the Mt Vettore fault, slow deformation affects an area of $\sim 50 \mathrm{~km}^{2}$ (Figure 2), and is associated with displacements in the 
LOS direction that are $13.2 \pm 1.4 \mathrm{~mm}$ in average at Point 2 on 6 January and reach $37.9 \pm 1.3 \mathrm{~mm}$ on 30 April 2017 (Figure 2-D and Figure 3-A).

To rule out possible bias due to the Campotosto earthquakes affecting the area near Castelluccio and near Arquata del Tronto, we confirmed these previous observations with a shorter time-series calculated between the Norcia and Campotosto earthquakes (November $1^{\text {st }}-$ January $12^{\text {th }}$ ) (Figure 4). We prefer to use, for the rest of the manuscript, the longer postNorcia time-series (November $1^{\text {st }}-$ June $11^{\text {th }}$ ) that shows a better signal-noise ratio.

In the post Amatrice earthquake time series (August 27 to October 26) we did not observe any localized surface displacements similar to the pattern observed after October 30 (Norcia earthquake) (Figure S4-B). Yet near the town of Amatrice, we observe diffuse surface displacements $(<\sim 2.5 \mathrm{~cm})$ moving away from the satellite. However, this time-series is constrained by only 9 scenes and 20 interferograms, which prevents from properly (i) constraining a low amplitude signal and (ii) correcting for atmosphere and topography. The surface displacements here have a low signal to noise ratio. The variance of the uncorrelated noise is $\sim 40 \mathrm{~mm}^{2}$ (see Supplementary Text S1 and Figure S5-A), and the standard deviation sigma of the noise is thus $6.3 \mathrm{~mm}$. We take $3^{*}$ sigma $=20 \mathrm{~mm}$ to set our limit of detection. The characteristic length scale of correlated noise is $5.0 \mathrm{~km}$ and there is autocovariance for distances smaller than $15 \mathrm{~km}$ (see Figure S5-A). Observed patterns cannot be differentiated from noise, analyses on SAR images from other satellites should be carried out to confirm or not the post-Amatrice (August 24 earthquake) surface displacements.

\subsubsection{Descending Track}

To confirm the post-October 30 (Norcia earthquake) observations we processed descending interferograms (Figure 2-C). We used a 3-month dataset for the descending track (November 1st, 2016 to February 11, 2017). Time-series calculated for the descending track also indicate slow deformation after Norcia earthquake (October, 30), that reaches on average $20.5 \pm 2.7 \mathrm{~mm}$ on January 24 in the LOS direction near Arquata del Tronto (point 1 ). The deformation reached on average $10.8 \pm 1.5 \mathrm{~mm}$ in the Castelluccio basin (in point 2). Assuming negligible north-south displacements, by combining the results from ascending and descending tracks, the displacement is dominated by subsidence in this area (Figure S6).

In the first order, deformation observed in the descending track is compatible with results inferred from the ascending track. Noise and unwrapping issues led us to mask noisy areas and resulted in more blank pixels in the descending track picture which should be used 
with caution. The relief projected in the descending LOS geometry masked a ridge (Mt Bove -

219 Mt Vettore - Mt Gorzano high massifs) (Figure S7). In addition to noise, this resulted in an

220 incoherent area and made unwrapping difficult in that area. The temporal evolution of the

221 features slightly differs from the one in the ascending track. The removal of the $7^{\text {th }}$ November

222 SAR images (affected by strong atmosphere conditions) and the poor constraint on the $19^{\text {th }}$

223 November SAR images (see the network in Figure S1) could affect the time-series in November.

224 Falcucci et al. (2018) had similar difficulties in using descending SAR images to survey the

225 January 2017 Campotosto seismic event. This might be due to the early morning acquisition

226 time, which amplifies decorrelation due to change of moisture level or thawing.

In addition, we produced time-series calculated between the Amatrice and Norcia earthquakes. This time-series is also affected by a short-wavelength atmospheric turbulence that makes it difficult to interpret (Figure S5-B-C). The variance of noise is $\sim 21 \mathrm{~mm}^{2}$. The characteristic length scale of correlated noise is $5.0 \mathrm{~km}$ and there is autocovariance for distances smaller than $\sim 15 \mathrm{~km}$ (see Figure S5). Again, displacement less than $19 \mathrm{~mm}$ for the ascending track and under $14 \mathrm{~mm}$ for the descending track, cannot be considered as detectable signal, therefore constraining smaller surface displacements between the Amatrice and Norcia events demands complementary time-series with SAR images from other satellite.

\subsubsection{Comparison with GNSS}

Few GNSS stations exist near the studied area (ARQT, LNSS see station locations in Figure 2-A). Those GNSS time-series agree with InSAR time-series sampled at the same locations 238 (Figure S8).

\subsection{Pattern temporal evolution}

240 By sampling the time-series, the temporal evolution is shown by averaging pixel 241 displacement in area. To enhance the precision of the displacement temporal evolution 242 without using time-series inversion, we temporally track a stable pattern in our unwrapped interferograms (Grandin, 2009). The method is detailed in Supplementary Text S2 and is

244 illustrated by Figures S9-S10.

245 This method can only be used on areas where the displacement pattern is well defined, 246 and works well in our case to track the evolution of the area near Arquata del Tronto (pattern 247 in Figure 4 which encompasses the point 1). After the Norcia earthquake, the amplitude ratio 248 is higher, and a logarithmic decay is clearly identified there (Figure 3-B). The pattern tracking 249 shows a temporal evolution similar to the averaging surface displacement method. We are 
therefore confident that pixel averaging adequately captures the evolution of displacement that we want to describe. For the descending interferograms, the pattern is not precisely trackable and its time evolution is noisy (grey curve in Figure S10-C). This could be due to a poor correlation for the pattern in some interferograms. The evolution of the pattern around Castelluccio Basin (pattern in Figure 4) is poorly resolved too.

\section{Modelling 3D deformation field 4.1 Comparison with topography and geology}

To interpret the displacement pattern near Arquata del Tronto we compared it with the topography and the geology. There is no correlation with either the slope or the relief (Figure S11), thus we can exclude a gravitational process (i.e. landslide) as an explanation for the observed displacements. Concerning geology, the OAS thrusts fractured Meso-Cenozoic carbonate rocks over Neogene pelagic sediments; the carbonates host some of the largest aquifers in the Apennines while the Neogene sediments are thought to be an aquiclude (Figure S12) (Boni et al., 2010). The OAS delimiting these two units therefore acts as an impermeable boundary (Boni et al., 2010). Petitta et al., (2018) and Valigi et al., (2019) show that the 20162017 Italian seismic sequence had effects on spring discharge, water-table levels, and streamflow of those aquifers. In our results, the extent of the Maiolica unit, which hosts a shallow aquifer (Boni et al., 2010), corresponds well with the deformation area near Arquata del Tronto (Figure S11-A-B). The long pre-seismic InSAR time-series did not show any seasonal deformation in this aquifer, which means that groundwater seasonal processes can be excluded (point 1 in Figure 2-D). In addition, it seems difficult to get more than $1 \mathrm{~cm}$ of subsidence from winter rain in this area (i.e., Silverii et al., 2016).

\subsection{Poro-elastic modelling}

Poro-elastic effects have been studied during the 2016-2017 seismic sequence to explore the aftershocks and earthquakes triggering. Tung \& Masterlark (2018) suggest that fluid migration caused by the Amatrice earthquake (August 24, 2016) could have triggered the Visso earthquake (October 26, 2016), as well as some associated aftershocks. They inferred that this poro-elastic triggering should have occurred in an intermediately fractured crust. They also estimated that afterslip and viscoelastic-relaxation were quite negligible with respect to poroelastic effects. Albano et al. (2018) also suggest that post-seismic fluid diffusion after the Amatrice earthquake is related to aftershocks. According to their pore fluid diffusion model, there could be some associated afterslip ( $10 \mathrm{~cm})$ after the Amatrice earthquake. 
The Maiolica karst aquifer is shallow and unconfined but Roeloffs (1996) postulates that every aquifer reacts as a confined aquifer to a disturbance at short timescale. Here, to compare with the displacement pattern near Arquata del Tronto, we thus test a forward model of poroelastic rebound using Relax software (Barbot \& Fialko, 2010). We perform a simple poro-elastic model with no lateral variation of diffusivity, that does not account for the spatially heterogeneous distribution of local aquifers. We use the slip distribution models of the Norcia and Visso mainshocks (Maubant et al., 2017), (Figure S13 and Figure 5-A). We do not take into account the Amatrice earthquake since poroelastic rebound from the Amatrice earthquake would likely have stabilized by the time of the Visso and Norcia earthquakes (Figure 4-f in Albano et al., (2018)). We tested several diffusivities for a shallow layer (0-5 km depth), from $1.5 \mathrm{~m}^{2} . \mathrm{s}$ proposed by the Tung and Masterlark (2018)'s aftershocks analysis to $10^{4} \mathrm{~m}^{2} / \mathrm{s}$ (maximum diffusivity value for karst) (Roeloffs, 1996). Other parameters are described in detail in Figure 5. This model predicts uplift in the Castelluccio Basin and near Arquata del Tronto (Figure 5-D) where we observe subsidence (Figure 5-C). This discrepancy allows us to rule out poro-elastic rebound as the main driver of observed deformation. These poroelastic models are not exhaustive, we only explore simple geometrical configurations using parameter values informed by the local geology, however, other karstic configurations would likely predict uplift as well.

\subsection{Viscoelastic modelling}

Viscoelastic relaxation in the crust and in the mantle is also an important aseismic process, and has been inferred to be the driver of post-seismic deformation following many earthquakes (e.g., Pollitz et al., 2001; Zhao et al., 2017). To test whether viscoelastic relaxation is a plausible driving mechanism for post-Norcia deformation, we used Relax to perform forward modelling in a simple layered framework. Our model uses the stress perturbation from the three mainshocks: the Amatrice earthquake using the slip distribution of Ragon et al., (2019) added to the Visso and Norcia earthquakes using the slip distribution model of Maubant et al., (2017). We set the upper, middle and lower crust thickness to the values proposed in Laske et al., (2013) and Verdecchia et., al. (2018) (see Table 1). We tested a viscoelastic relaxation governed by a Newtonian rheology with $\dot{\gamma}=\frac{\tau}{\eta}$ where $\dot{\gamma}$ is the viscous

311 strain rate, $\tau$ is the deviatoric stress and $\eta$ is the Newtonian viscosity. We used viscosity values

$312 \eta$ inferred in studies of viscoelastic relaxation modelling using GPS measurements following 3131997 Umbria-Marche earthquakes, or using levelling line measurements following the 1915 
314 Fucino earthquake (Amoruso et al., 2005; Aoudia et al., 2003; Riva et al., 2007). These studies

inferred that the ductile structure of the Central Apennines consists of an elastic upper crust overlaying a middle crust $\left(10^{18}-10^{19} \mathrm{~Pa} \mathrm{~s}\right)$, a viscous lower crust $\left(10^{17}-10^{18} \mathrm{~Pa}\right.$ s) and the upper mantle (1021 Pa s) (Table 1).

Although those models are geometrically simple and do not take into account earthquakes prior 2016, they predict at a long-wavelength uplift (>50 km) in the area where we observe subsidence (Figure 6). This discrepancy in both sign and wavelength allows us to rule out a simple visco-elastic relaxation as the main driver of observed deformation. Viscoelastic models are not exhaustive here: nonlinear viscoelastic rheologies (e.g., power law creep) in lower crust (Freed \& Bürgmann, 2004) could also be investigated; however finite element models with creeping lower crust seem also to predict uplift in similar settings of normal fault systems (e.g., Thompson \& Parsons, 2016). It is worth also mentioning that the observed logarithmic decay could also potentially be associated with Burgers rheology or shear zone (e.g., Hetland \& Zhang, 2014) and could also be investigated in future work. Although, as with the poroelastic modeling, it seems unlikely that a different geometry or rheology could completely reverse the sign of uplift and subsidence (for example, a different rheology would only affect the temporal evolution/spatial distribution).

\subsection{Modelling the temporal evolution of afterslip}

The logarithmic-like temporal evolution of displacement (Figure 3-A), and the disagreement between the observations and the predictions of poroelastic and viscoelastic models, suggest that afterslip may have been the main driver of postseismic deformation (Marone et al., 1991). Thus to characterize the temporal evolution of the deformation, we fitted the deformation decay (of the raw time-series and of the pattern tracking evolution) with the logarithmic function (Figure 3-A-B respectively) from the Marone et al. (1991) model and Zhou et al. (2018) reformulation for rate-strengthening afterslip:

$$
\begin{gathered}
U(t) \approx \alpha \times \ln (1+c \times t) \\
c=\frac{\beta \times V_{i}}{\alpha}
\end{gathered}
$$

In which $U$ : afterslip in time $t, \alpha$ : characteristic length scale, $\beta \times V_{i}$ : initial rate at the beginning of the post-seismic period, with $\beta$ a scaling vector by which the sliding rate evolves in response to the stress and $V_{i}$ the pre-seismic slip rate. 
At point 1 (near Arquata del Tronto), the good fit of the afterslip model suggests that the main post-seismic process is likely an afterslip phenomenon. Since we found similar results for c value (describing the temporal decay) using the raw pixel time series and using the pattern tracking (independent for the time-series inversion), we are confident in our fitting (Table 2). The first post-Norcia Sentinel image has been acquired 2.6 days after the Norcia earthquake; therefore those 2.6 days of early afterslip are missing in our data. We compare the temporal decay of the deformation with the cumulative moment and number of aftershocks (blue and green curves in Figure S14). Although the completeness magnitude is high (ML 3 in Figure S5 in Chiaraluce et al., (2017)), those two curves obtained with less than 50 events are not following the same trends, aftershocks do not seem to be induced by afterslip. At point 2 (near Castelluccio di Norcia), the temporal decay does not fit with the afterslip law as the rate at the beginning of the post-seismic period is close to zero (c value for the purple curve fit in Figure 3-A). Other post-seismic processes could be a complementary driver of the deformation here and should be taken into account in further modelling (i.e. finite element forward model accounting for afterslip superimposed with poro-elastic rebound and viscoelastic relaxation).

\subsection{Afterslip modelling on faults}

\subsubsection{Inversion strategy and fit to the data}

To obtain the afterslip distribution we use the Classic Slip Inversion (CSI) Python tools (Elliott, Jolivet, et al., 2016; Jolivet et al., 2015) to invert for the slip. We use the constrained least-squares formula of Tarantola (2005) to solve the inverse problem (see details in Supplementary Text S3 and Figures S15 to S18). We chose a dip of $40^{\circ}$ for the Mt Vettore fault (as Cheloni et al., (2017) see Figure S15) and project the fault down dip from the mapped fault at the surface (modeled fault geometry in yellow Figure 2-A). We discretize the fault into 88 rectangular patches. The smoothed cumulative surface displacement on February 11, 2017, measured in both ascending and descending tracks are inverted to obtain the afterslip distribution. The resolution is good for short-wavelength features at shallow depths $(<5 \mathrm{~km}$ depth) (Figure S16). As several geometries have been used to model the mainshock rupture (OAS reactivation, antithetic fault), we explored three cases: (1) slip only on the Mt Vettore Fault, (2) slip on the Mt Vettore Fault and on the OAS and (3) slip on the Mt Vettore Fault and an antithetic fault with a geometry similar to the one proposed by Cheloni et al., (2019) and Maubant et al., (2017) (dip 65\%) (Figures S17 to S20). We also explored the rake: (1) dip-slip only and (2) variable rake. A rigorous statistical comparison between the cases is difficult due 
to variation in model parameters and number of degrees of freedom, as explained by Cheloni et al., (2019). We thus used the RMS values to compare the different cases. Here the case that reduces the residuals the most is the inversion with an antithetic fault. This case is in addition consistent with geological and seismological observations (i.e. Cheloni et al., 2019). The different cases were compared using the RMS (root mean square), and allows us to choose the inversion with an antithetic fault (Table S2).

Both ascending and descending tracks are well modelled (Figure 7). It is worth noting that the resolution is low at depth (Figure S16). The total geodetic moment released by the afterslip model is equivalent to $\mathrm{Mw} \sim 5.78$ (without taking into account the Campotosto earthquake) which corresponds to $\sim 8.7 \%$ of the geodetic moment released during the Norcia earthquake (Mw 6.5).

\subsubsection{Afterslip distribution}

\subsubsection{Near Arquata del Tronto}

We obtain a maximum afterslip of $\sim 100 \mathrm{~mm}$ below Arquata del Tronto at shallow depth (0- $2 \mathrm{~km}$ depth) (Figure 7 Figure 8). The shallow part depth $<3-4 \mathrm{~km}$ toward the south is associated with very low coseismic slip for both the Norcia and Amatrice earthquakes and is located at the edge of the coseismic asperities. This is also consistent with an afterslip process: the afterslip is located where the slip gradient increased the shear stress on the unruptured portions. This feature has also been observed after the L'Aquila earthquake (D'Agostino et al., 2012). We calculate a geodetic moment released equivalent to $M w \sim 5.1$ in this area (patches above $2 \mathrm{~km}$ depth and south of Arquata del Tronto). The cumulative moment released by the seismicity (Figure S14-D) at this date corresponds to $\sim 2.0 \%$ of the moment released by the afterslip model. The deformation is thus mainly aseismic.

Brozzetti et al., (2019) found some surface ruptures south of the $30^{\text {th }}$ October Norcia rupture $\left(42^{\circ} 47^{\prime} \mathrm{N}\right.$ in their Fig. $\left.1-\mathrm{C}\right)$ mapped by Villani et al., (2018). The ruptures mapped by Brozzetti et al., (2019) are subtle and according to us may correspond to post-seismic deformation, as was observed after the L'Aquila earthquake (D'Agostino et al., 2012).

\subsubsection{Castelluccio Basin}

We observe a maximum slip of $\sim 170 \mathrm{~mm}$ below Castelluccio at $\sim 5 \mathrm{~km}$ depth. Some afterslip overlaps with the coseismic rupture area, but not in the area of maximum coseismic slip (Figure 7). As also the shape of the measured time-series did not fit with the afterslip's law 
408

409

410

411

412

413

414

415

416

417

418

419

420

421

422

423

424

425

426

427

428

429

430

431

432

433

(Figure 3-A), a sole afterslip process is unlikely. It is possible that poroelastic and fluid flow processes could be at work here since there is a large basal aquifer (Boni et al., 2010). Modelling accounting for both processes could be performed, for example fully coupled poroelastic finite element numerical modelling with spatially variable material properties (e.g., Albano et al., 2017).

\section{Discussion}

\subsection{Afterslip mechanism near Arquata del Tronto}

Based on Dietrich (1979), Ruina (1983) and Marone et al., (1991) equations, we estimated $\alpha$ (the characteristic length scale over which the elastic stress changes by order of the frictional stress) in Figure 3 and Table 2. We can now estimate the friction parameter $(a-b)$ since according to Perfettini and Avouac (2004) and Zhou et al., (2018):

$$
\alpha=\frac{(a-b) \times \sigma}{k}
$$

with $\mathrm{k}$ : the effective stiffness, and $\sigma$ the effective normal stress. This relation can be applied to our case since the duration of our analysis ( 200 days) is much shorter than the characteristic time $t d$ (Gualandi et al., 2014). Where $t d=\frac{\alpha}{V p l}\left(>12\right.$ years) where $V_{p l}$ is the local plate loading rate $(<2.1 \mathrm{~mm} / \mathrm{yr}$ (Puliti et al., 2020)). The fit to the displacement of the timeseries sampled in point 1 by an afterslip law (Figure 3 ) leads to $\alpha=30.9 \pm 4.0 \mathrm{~mm}$. To estimate $\sigma$, we assume that the mean normal stress may vary from the hydrostatic to lithostatic pressure, with a rock density of $2.5 \mathrm{~kg} \cdot \mathrm{m}^{-3}$ (Albano et al., 2018) and a depth of the slipping area of 3-5 km. This leads to $\sigma=44-124 \mathrm{MPa}$. For $\mathrm{k}=\mathrm{G} / \mathrm{h}$ with $\mathrm{G}=30 \mathrm{GPa}$ (the shear modulus near the surface) and $\mathrm{h}=8 \mathrm{~km}$ (rate-strengthening depth based on the coseismic slip models), we obtain $(a-b)=3 \times 10^{-3}-7.8 \times 10^{-4}$. More complex models (e.g. finite element model, heterogeneous ( $a-b)$ values) could be performed by future studies in order to reproduce the surface displacements and to propose a more precise value of (a-b). However, our estimation is in agreement with experiments on carbonates. Scuderi and Collettini (2016) found values of $(a-b)$ evolve from velocity strengthening behaviour $(a-b \approx 0.005)$ at fluid pressure condition of sub-hydrostatic to a velocity neutral behaviour ( $a-b$ approaching 0$)$, when the fault is at near lithostatic fluid pressure. Pluymakers et al., (2016) found that wet anhydrite and dolomite gouges at depths $<6 \mathrm{~km}$, exhibit (a-b) values ranging from $10^{-2}$ to $10^{-4}$. 
In Arquata del Tronto, the obtained (a-b) positive value (0.0026) is in agreement with a velocity-strengthening area. The obtained $(a-b)$ value is also very low and corresponds to a quasi-neutral rate-dependency of friction implying a high sensitivity to stress perturbations. Potential stress perturbations needed to reach strengthening may involve either a decrease in effective normal stress and / or an increase in shear stress (Scholz, 1998). Walters et al., (2018) calculated the Coulomb stress change (CFF) after the Norcia earthquake. At shallow depths, they found a positive CFF change below Arquata del Tronto, which might have triggered the observed afterslip in this area. An increase in pore fluid pressure would have a similar effect. The afterslip is located near to the Olevano-Antrodoco-Sibillini (OAS) thrust. Chiarabba et al., (2018) detected a high Vp/Vs near the OAS thrust (around $3 \mathrm{~km}$ depth), indicating high pore pressure that could have been further increased by nearby major shocks (Amatrice and Norcia earthquake). This high pore pressure could have induced the observed afterslip allowing for the release of the residual accumulated stress. This scenario is also supported by the fact that pore fluid pressure variation is common in this area, where the inherited structures seem to control the rupture pattern and could also concentrate high shear stress. Future work could examine detailed Coulomb Stress modelling with high spatial resolution taking all fault complexity and pore fluid effects into account. These works could be useful, despite some limitations related to the resolution of the coseismic slip and by the ambiguity about which faults were involved.

If this overlapping of coseismic slip and afterslip is real below 4-5 km depth (below Arquata del Tronto) could be an artefact caused by the smoothing used to regularize the inversion of the slip distribution, combined with the fact that the resolution at depth is limited. If this overlapping of co-seismic and slow slip was confirmed, a simple interpretation of rate and state friction cannot be proposed here. Overlaps between coseismic slip and afterslip have been observed after several earthquakes. For example after $2004 \mathrm{Mw}_{w} 6$ Parkfield earthquake, afterslip was inferred to overlap the coseismic slip (Freed, 2007). Johnson et al., (2006) proposed frictional spatial heterogeneity to explain the afterslip distribution, and proposed (ab) values on the order of $10^{-4}-10^{-3}$. After the 2015 Ilapel $\mathrm{Mw}_{w} 8$ megathrust earthquake, Barnhart et al. (2016) also observed afterslip and coseismic slip overlapping, and advocated that stress heterogeneities likely provide the primary control on the afterslip distribution. After the 1978 Mw 7.3 Tabas-e-Golshan earthquake, Zhou et al., (2018) also observe such overlapping and found $(a-b) \sim 3.10^{-3}$. They proposed that the fault is creeping during the whole 
interseismic period and that the earthquake propagates through the rate-strengthening region

471 although they also stated that a change in frictional properties is also possible due to shear

472 heating. Thomas et al., (2017), after the $2003 \mathrm{Mw} 6.8$ Chengkung earthquake estimated that

473 (a-b) varies with depth from 0.018 near the surface to less than 0.001 at depth larger than 19

$474 \mathrm{~km}$, to explain areas showing both seismic and aseismic behavior they advocated shear heating

475 processes. Using numerical modelling, Noda and Lapusta (2013) argued that coseismic slip could propagate into velocity-strengthening regions of a fault, and that these regions can appear locked or creeping during the interseismic period. They observed this behavior due to rapid shear heating. For our case it is difficult to pinpoint the particular fault zone mechanism here, but we can propose a switch to (a-b) positive value below 4-5 km depth, due to coseismic shear heating processes (Thomas et al., 2017) requiring temperature changes of several hundred degrees (e.g., Rice, 2006). This could be a potential explanation since Smeraglia et al., (2017) suggested that nanostructures from the Mt Vettoreto Fault rocks were generated by coseismic shear heating and grain comminution (reduction of particle sizes).

\subsection{Barrier of rupture propagation}

Near Arquata del Tronto, at shallow depth $(<3-4 \mathrm{~km})$ we observe that the aseismic slip is localized on an area associated with limited coseismic slip, for both the Amatrice and Norcia earthquakes. The observed aseismic slip seems located in an area where coseismic ruptures have not propagated during the Norcia or Amatrice earthquakes. This slowly slipping zone is located near a structural complexity (inherited thrust OAS), that Chiaraluce et al., (2017), Pizzi et al., (2017) and Puliti et al. (2020) interpreted as a barrier that concentrated stress after the Amatrice earthquake. We propose that maybe as a result of this geometric complexity (that may concentrate high stress and high porosity resulting from fracturation), this zone might be also characterized by frictional properties at shallow depth that could have favoured the arrest of the ruptures (e.g., Kaneko et al., 2010). Scholz (1998) shows that when an earthquake propagates into a velocity strengthening field it will produce a negative stress drop, that rapidly terminates propagation. Our simple calculations yield here a slightly positive (a-b) value, consistent with this model. 
The Sentinel-1 InSAR time-series show $\mathrm{cm}$-scale post-seismic displacements after the

501 Norcia earthquake (October 30). The displacements are more obvious in the ascending track

502 than in the descending track, and correspond to $\sim 1$ to $5 \mathrm{~cm}$ of subsidence in the Castelluccio

503 basin and at the southern tip of the Norcia surface rupture. In the area of the Castelluccio

504 basin, whether the deformation can be explained by afterslip only is less clear and would

505 require additional modelling to include the effects of poro-elastic release or shear zone

506 deformation. At the southern edge of the Norcia coseismic rupture, deformation evolves with

507 time following a logarithmic decay consistent with afterslip triggered by the Norcia

508 earthquake. Although good observations of the 2.6 first days of afterslip are not available, after

5093 months the slow deformation evidenced in this study released a geodetic moment of $\mathrm{Mw}$ $\sim 5.78$, which corresponds to $\sim 8.7 \%$ of the geodetic moment released during the Norcia earthquake. Cumulated moment released by aftershocks in the southern tip of the Norcia rupture accounts for $\sim 2.0 \%$ of the moment released by the modelled deformation, the deformation is thus here mainly aseismic. This afterslip takes place at the southern tip of the

514 Norcia rupturing patch, and seems to have acted as a barrier to the propagation of Norcia and

515 Amatrice ruptures at shallow depth $(<3-4 \mathrm{~km})$. Our results suggest that the observed post-

516 Norcia earthquake afterslip might have been triggered in response to heterogeneities of pore

517 fluid pressure, potentially facilitated by structural complexity and intense faulting in the area.

518 Such small and localized slow deformation due to afterslip may be best detected with InSAR

519 time-series in regions of sparse GNSS coverage. It might actually be quite common and could

520 be an underestimated phenomenon. This likely points toward a bias in the literature in favour

521 of high and wider afterslip, that is easier to detect. However detection of small afterslip

522 transient is crucial to further understand the physics of earthquakes, and the link between

523 slow slip and seismic rupture (e.g., Kaneko et al., 2010; Rousset et al., 2017). 


\begin{tabular}{|c|c|c|c|c|c|}
\hline & Depths (km) & Model 1 n & Model $2 n$ & Model 3 n & Model $4 \eta$ \\
\hline Upper crust & $0-10.7$ & Elastic & Elastic & Elastic & Elastic \\
\hline Middle crust & $10.7-21.7$ & Elastic & $10^{19} \mathrm{~Pa} \mathrm{~S}$ & $10^{18} \mathrm{~Pa} \mathrm{~S}$ & $10^{18} \mathrm{~Pa} \mathrm{~S}$ \\
\hline Lower crust & $21.7-33.1$ & $10^{18} \mathrm{~Pa} \mathrm{~s}$ & $10^{18} \mathrm{~Pa} \mathrm{~s}$ & $10^{18} \mathrm{~Pa} \mathrm{~s}$ & $10^{17} \mathrm{~Pa} \mathrm{~s}$ \\
\hline Upper mantle & 33.1-below & $10^{21} \mathrm{~Pa} \mathrm{~s}$ & $10^{21} \mathrm{~Pa} \mathrm{~s}$ & $10^{21} \mathrm{~Pa} \mathrm{~s}$ & $10^{21} \mathrm{~Pa} \mathrm{~S}$ \\
\hline
\end{tabular}

529

530 Table 1 : Crust and mantle viscosities ( $\eta$ ) tested in Figure 6.

531

532

5337.2 Table 2

534

\begin{tabular}{lcllr}
\multicolumn{1}{c}{ Fit } & $\boldsymbol{\alpha}$ & \multicolumn{1}{c}{$\boldsymbol{C}\left(\right.$ days $\left.^{-1}\right)$} & $\boldsymbol{\gamma}$ & R2 \\
\hline $\begin{array}{l}\text { Point 1 near Arquata del } \\
\text { Tronto }\end{array}$ & $30.9 \pm 4.0$ & $0.26 \pm 0.26$ & $-6.4 \pm 6.2$ & 0.87 \\
\hline $\begin{array}{l}\text { Point 2 near Castelluccio } \\
\text { di Norcia }\end{array}$ & $156.4 \pm 230.7$ & $0.003 \pm 0.007$ & $2.54 \pm 3.5$ & 0.81 \\
\hline Pattern tracking & $1.6 \pm 0.1$ & $0.24 \pm 0.1$ & $-0.37 \pm 0.21$ & 0.95 \\
\hline
\end{tabular}

535

536 Table 2: Parameters obtained from the fit of the afterslip model in Figure 3 using a non-linear

537 least squares method (Moré, 1978). R2 is the coefficient of determination of the regression.

538 The pattern encompasses the point 1 (see Figure 4)

539 

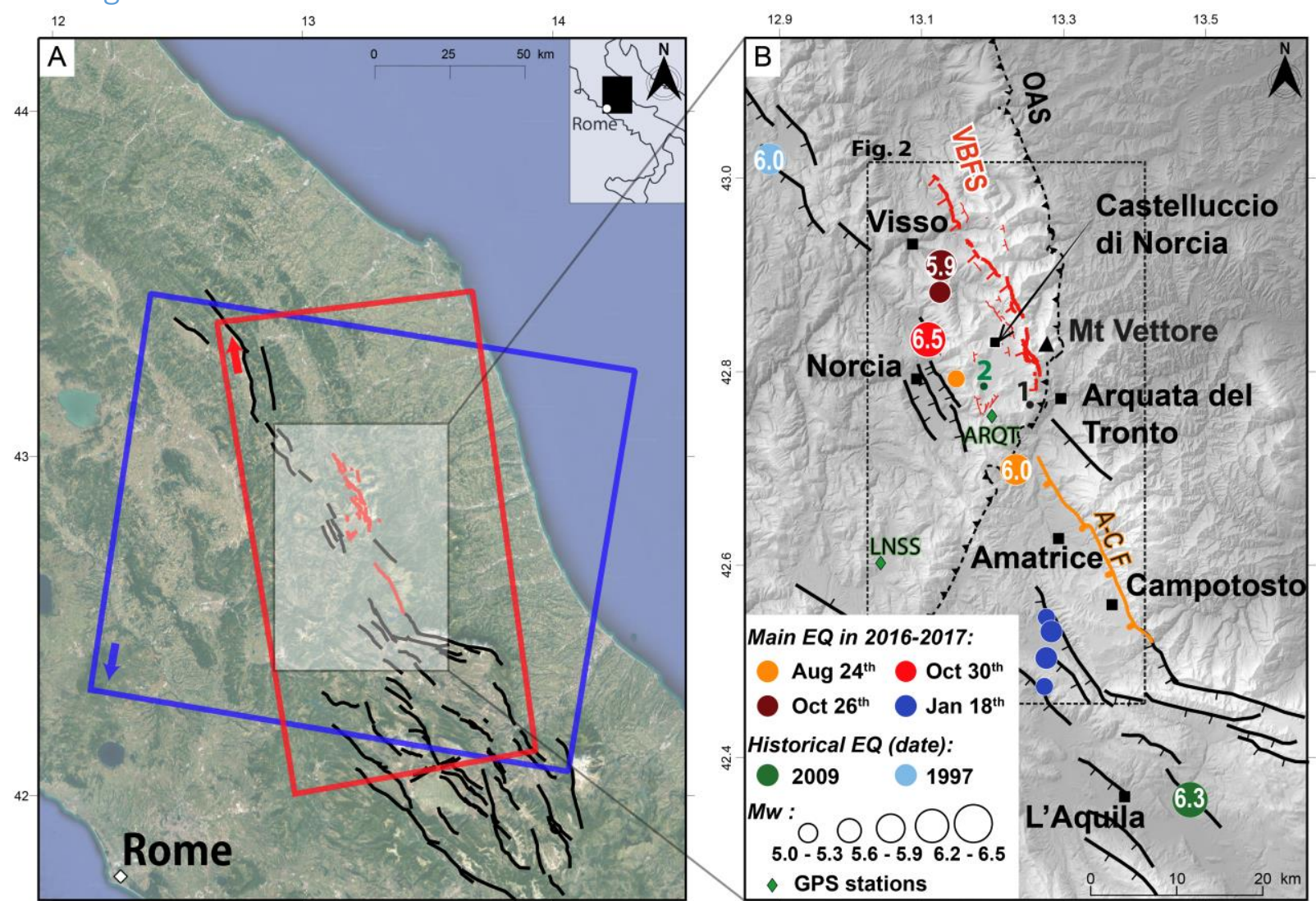

542

543 Figure 1: Neotectonic framework of the Central Apennines. Black lines are main normal active

544 faults compiled from Benedetti (1999), Tesson et al., (2016) and references therein (VBFS: Mt

545 Vettore - Mt Bove Fault System, A-C F: Amatrice-Campotosto Fault). In red, coseismic surface ruptures observed in the field after the mainshocks of the Central Italy 2016-2017 seismic

547 sequence (Villani, Civico, et al., 2018). (A) Blue and red rectangles are, respectively, the

548 descending (D22 subswaths IW2 and IW3) and ascending (A117, subswath IW3) Sentinel tracks

549 processed in this study. (B) Black dashed line represents the Neogene OAS thrust (Olevano-

550 Antrodoco-Sibillini thrust) (Di Domenica et al., 2012). In orange the Amatrice-Campotosto fault

551 which was activated during the 2016-2017 seismic sequence. ARQT and LNSS (in B) are GNSS

552 stations available in this region

553 http://geodesy.unr.edu/NGLStationPages/gpsnetmap/GPSNetMap MAG.html (Blewitt et al., 554 2018). 


\section{Post $30^{\text {th }}$ oct. earthquake :}
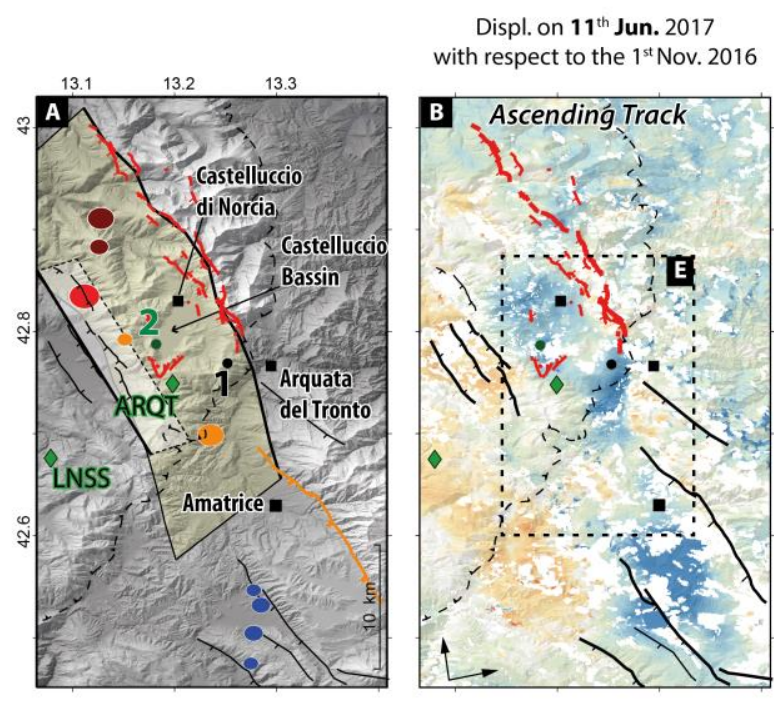

Displ. on $\mathbf{1 1}^{\text {th }}$ Feb. 2017
with respect to the $1^{\text {st }}$ Nov. 2016
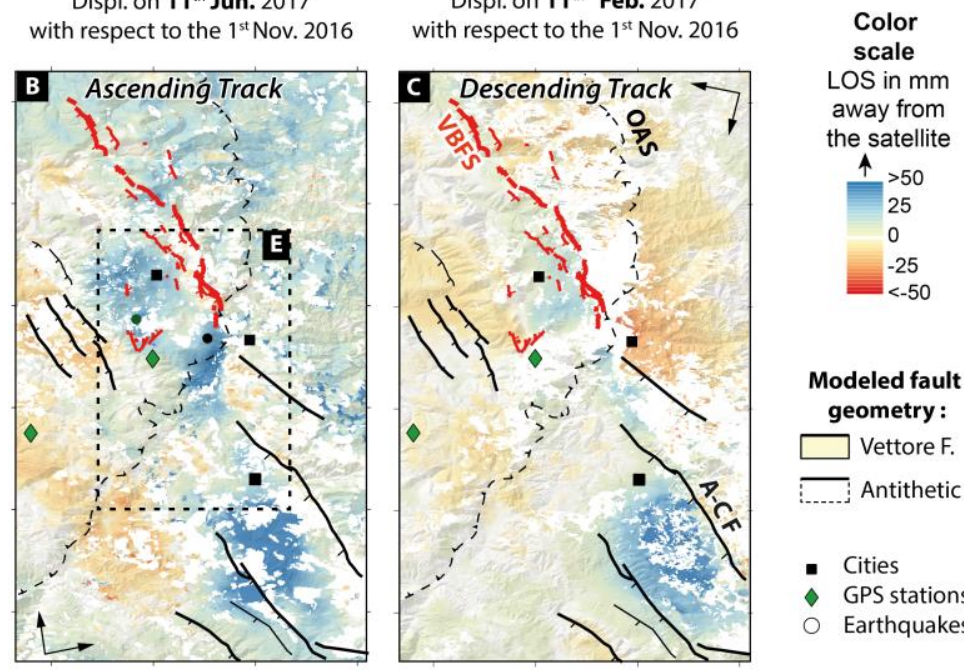

Modeled fault geometry:

Vettore $F$.

Antithetic F.

- Cities

GPS stations

○ Earthquakes

\section{Raw data (Ascending Track)}

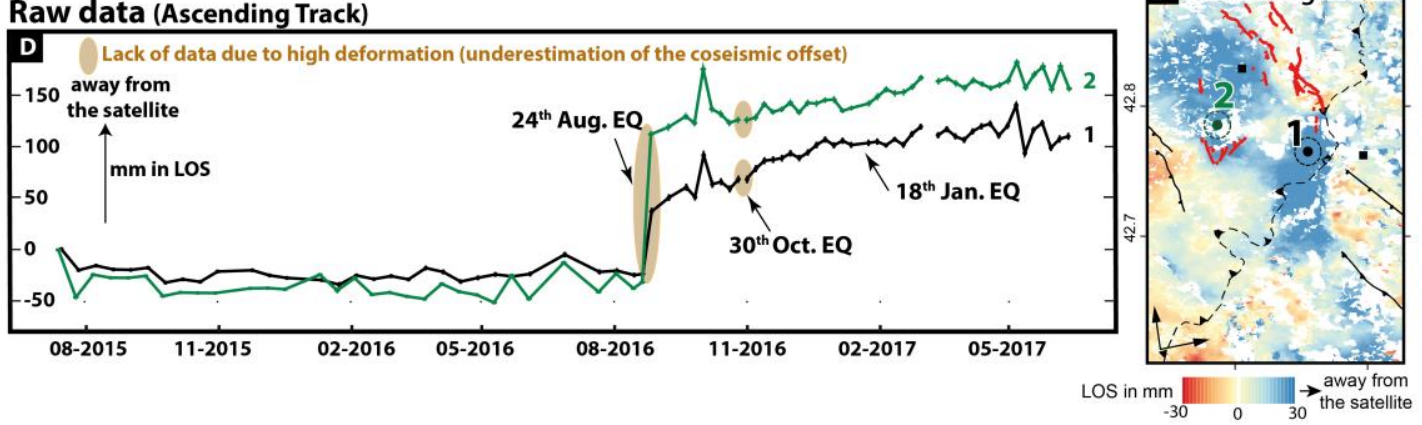

Figure 2: (A) Map of the studied area, green squares are the GPS stations, points 1-2 are the points of sampling. The modeled geometries of the Mt Vettore and antithetic faults are plotted (see section 4.5). Circles are the earthquakes (see Figure 1). (B-C): Time-series calculated cumulative post-Norcia (30 oct) displacements for ascending (B) and descending track (C), respectively. In panels $A, B, C, E$ : Red lines are surface ruptures associated with $30^{\text {th }}$ October 2016 Norcia earthquake (Villani, Civico, et al., 2018), and black lines are active faults. Black dashed line is the OAS thrust. (VBFS: Mt Vettore - Mt Bove Fault System, A-C F: AmatriceCampotosto Fault, OAS: Olevano-Antrodoco-Sibillini thrust). (D) Displacement through time averaged over a circle of 20 pixels (dashed circles in panel E) in diameter around points 1-2. (E) Cumulative displacement on June 11, 2017, with respect to the $1^{\text {st }}$ November 2016 date. 
570

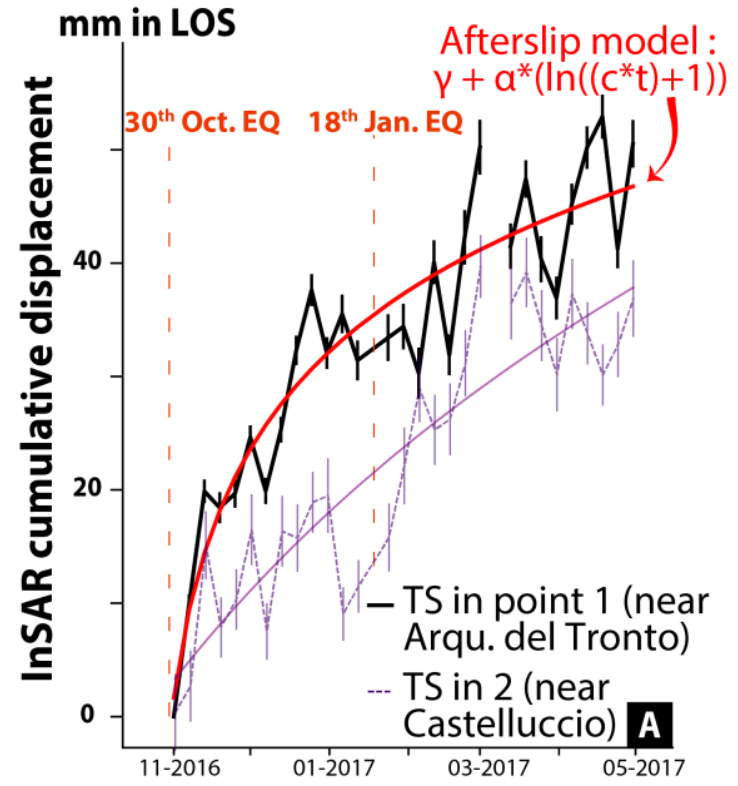

Time in months

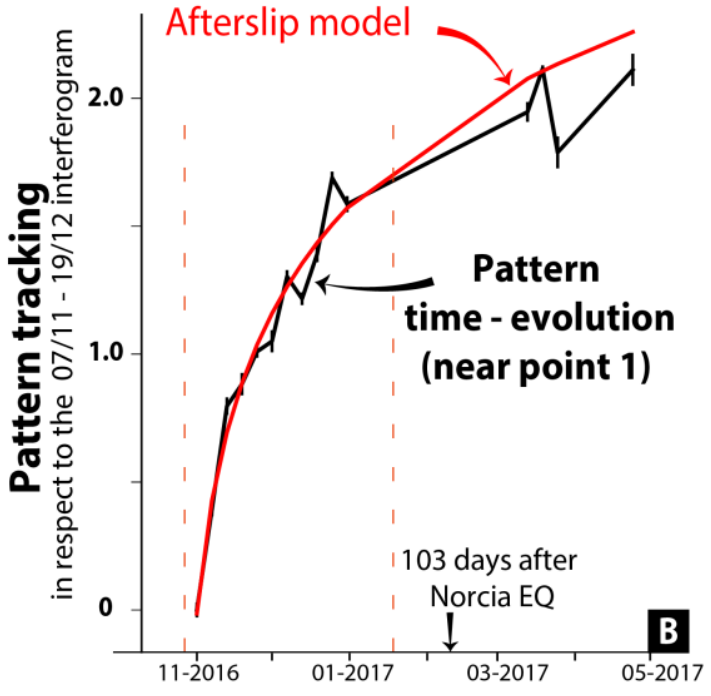

Time in months

573 Figure 3: (A) Temporal variation of displacement averaged over a circle of 20 pixels in diameter

574 through time of point 1 (black curve) and 2 (purple dashed curve) localized in Figure 2-E. We 575 fitted the curve with afterslip model (see results in Table 2).

576 (B) Temporal variation of pattern amplitude. Pattern is indicated in Figure 4. In red, the fit with 577 an afterslip model (see results in Table 2). 


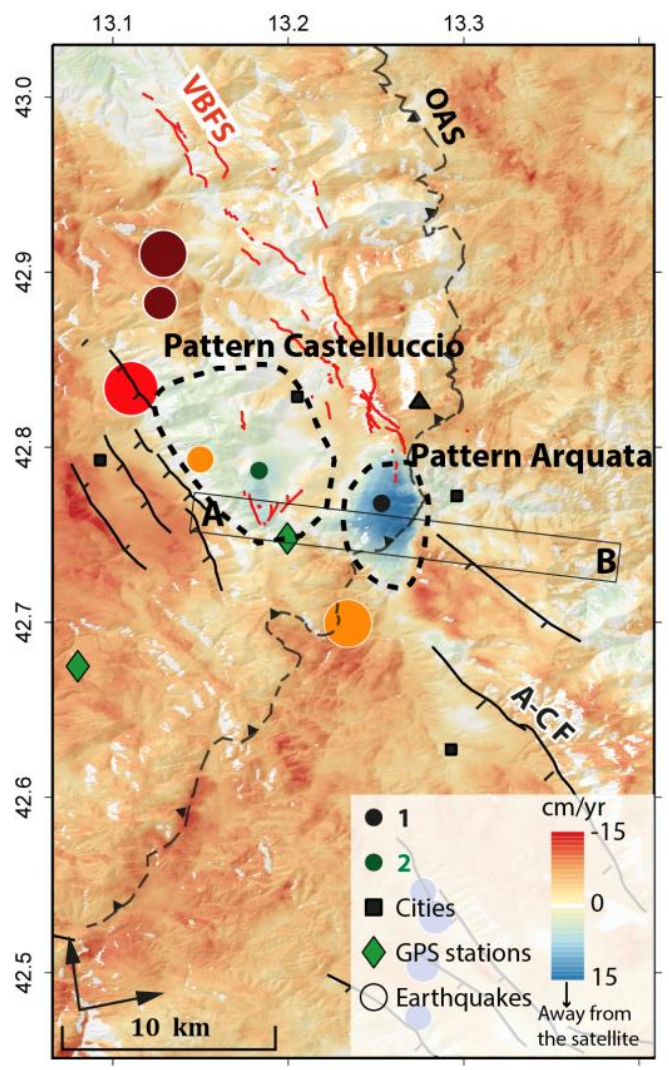

583 Figure 4: Mean velocity map between Mw 6.5 Norcia and Mw 5.7 Campotosto earthquakes

584 (November $1^{\text {st }}-$ January $12^{\text {th }}$ ). This map is computed using 35 ascending interferograms. The 585 swath A-B is used in Figure S11 to compare InSAR displacements and topography. Circles 586 represent the earthquakes (see color code in Figure 1). 
Coseismic slip (Norcia + Visso EQ) Maubant et al., 2017

$0 \quad 10 \quad 60 \quad 120180$

Contour of the Mt Vettore F.

$[\ldots$ Contour of the Antithetic $F$.

- $\sigma k k$ (MPa),

calculated in a undrained homogenous elastic medium
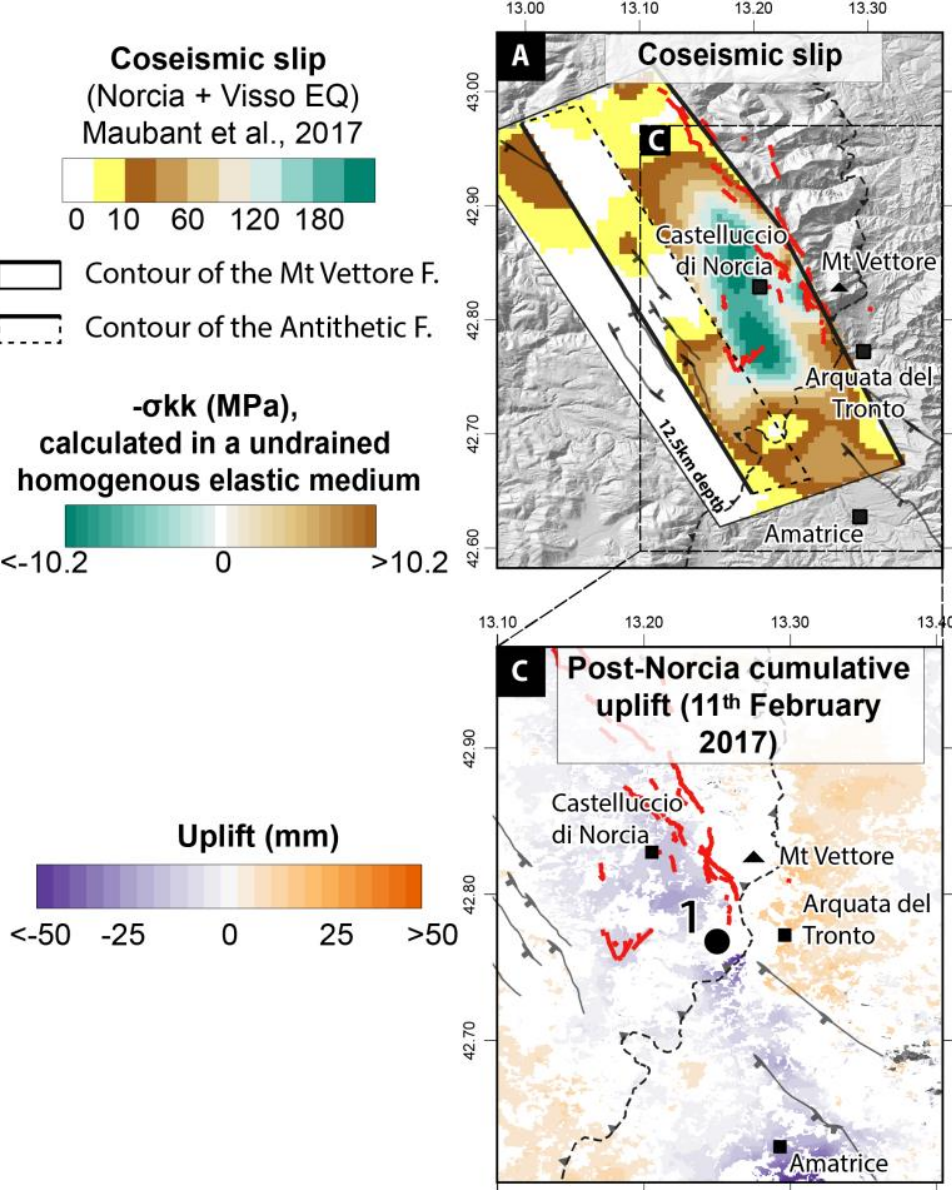

Time-series of modeled poro-elastic rebound at point 1.

— Diffusivity $=1.5 \mathrm{~m}^{2} / \mathrm{s}$

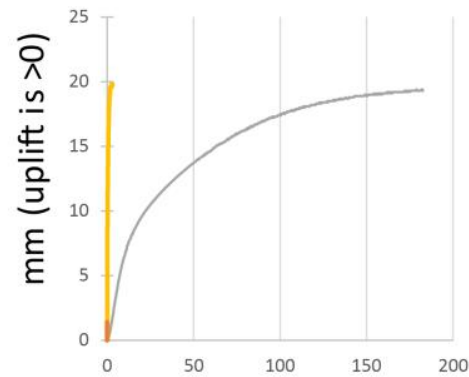

E
— Diffusivity $=1500 \mathrm{~m}^{2} / \mathrm{s}$

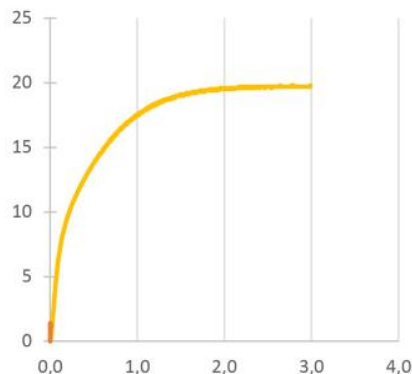

Days Post-Norcia
Days Post-Norcia
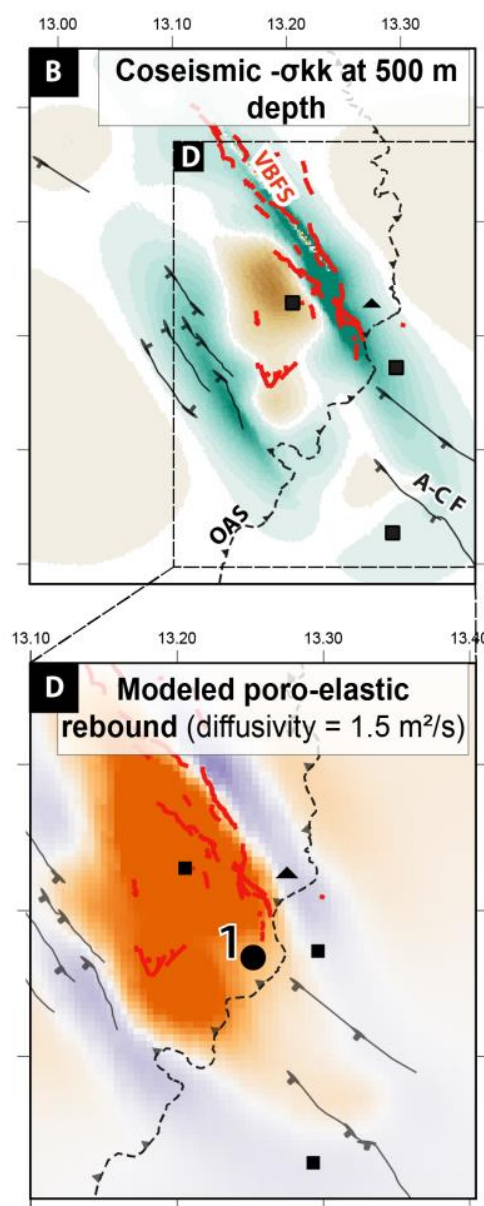

Diffusivity $=10000 \mathrm{~m}^{2} / \mathrm{s}$ (maximum value for karst in Roeloffs 1996)

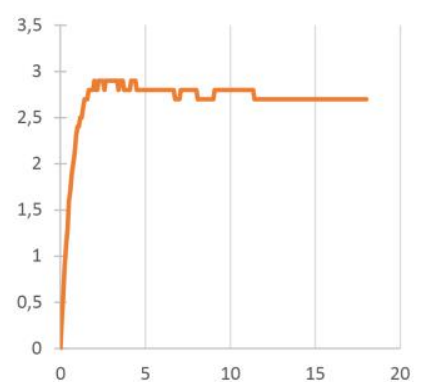

Minutes Post-Norcia

591 Figure 5: Poro-elastic rebound modelled with Relax software (Barbot \& Fialko, 2010). We used

592 the coseismic slip models of the Norcia and Visso earthquakes from Maubant et al., (2017).

593 (A) Mapview of the coseismic slip distribution. (B) Coseismic - $\sigma$ kk modelled at 500m depth,

594 calculated in an undrained homogenous elastic medium (Poisson v=0.34; Lamé $\lambda=6.36 E+04$

$595 \mathrm{MPa}$, shear modulus $\mathrm{G}=30 \mathrm{GPa}$, Gravity wavelength $\gamma=5.39 \mathrm{E}-04 \mathrm{~km}^{-1}$ ). To remind, the pore pressure change $(\Delta p)$ is equal to $-B^{*} \sigma k k / 3$, with (B the Skempton's coefficient). (C) Post-Norcia cumulative displacement map (11 $1^{\text {th }}$ February 2017) observed by InSAR (uplift component). (D) 
598 Model-predicted poro-elastic rebound as of $25^{\text {th }}$ February 2017, obtained using the difference 599 between drained and undrained conditions. Poisson drained is 0.26 (cf. layer 1 in Albano et al. 600 2018), and for undrained conditions is 0.34 (from beta=0.4 in the table 1 and equation 15 in 601 Barbot et al., (2010)). The layer between $(0$ and $5 \mathrm{~km})$ is characterized by a diffusivity equals 602 to $1.5 \mathrm{~m}^{2} / \mathrm{s}$ (Tung \& Masterlark, 2018). (E) Modelled poro-elastic rebound time-series at point 603 A using several diffusivities, from $1.5 \mathrm{~m}^{2} / \mathrm{s}$ (Tung \& Masterlark, 2018) to $10^{4} \mathrm{~m}^{2} / \mathrm{s}$ (Roeloffs, 604 1996). Because the delay time is inversely proportional to the assumed diffusivity, the 605 response for high diffusivity is shorter. (VBFS: Mt Vettore - Mt Bove Fault System, A-C F: 606 Amatrice-Campotosto Fault, OAS: Olevano-Antrodoco-Sibillini thrust). 607 

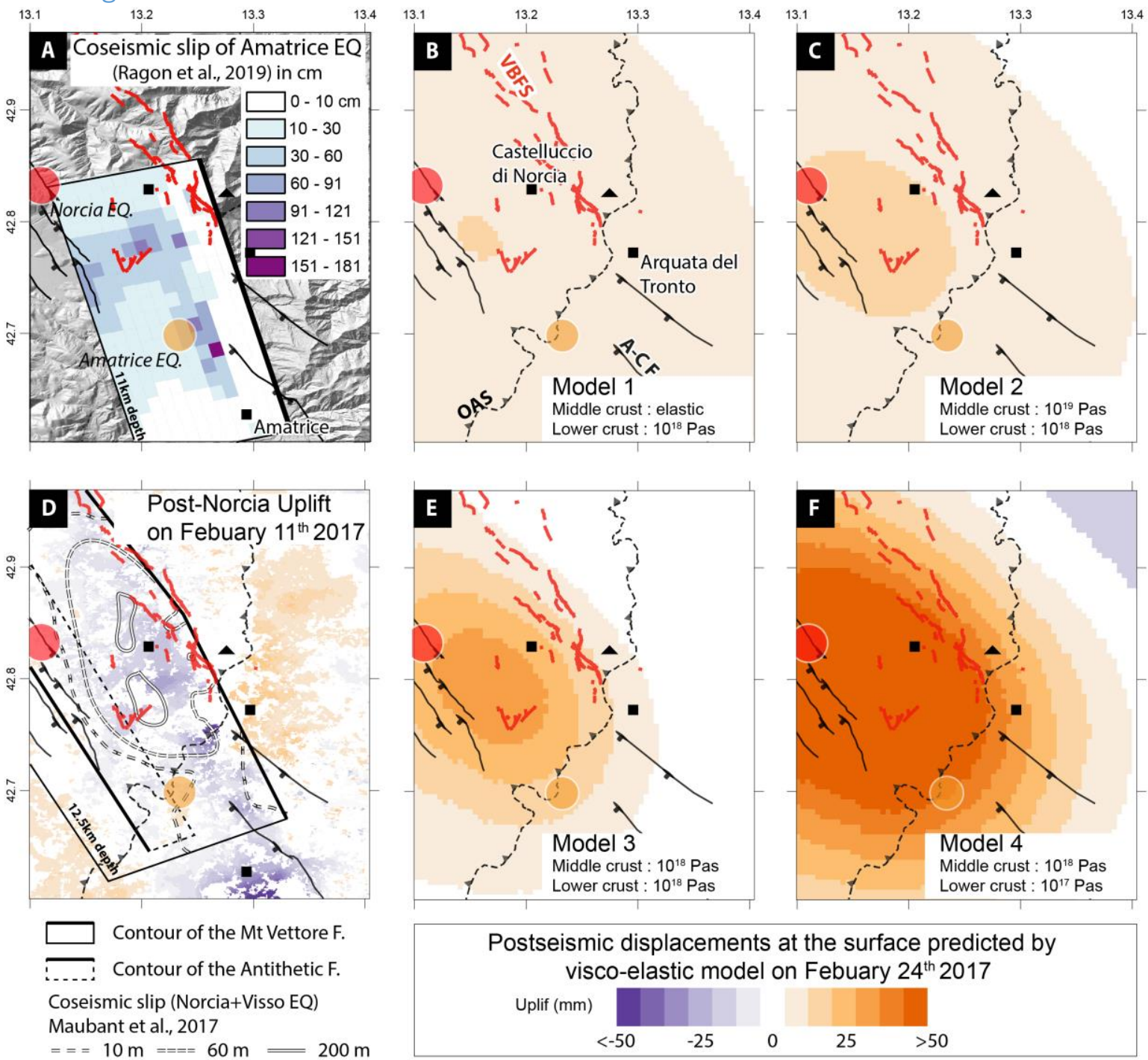

Postseismic displacements at the surface predicted by visco-elastic model on Febuary $24^{\text {th }} 2017$

Uplif $(\mathrm{mm})$

$$
\begin{array}{lllll}
<-50 & -25 & 0 & 25 & >50
\end{array}
$$

Figure 6: Surface displacements predicted by visco-elastic models, we used the Amatrice,

Norcia and Visso earthquakes coseismic slip distribution modelled by Ragon et al., (2019) and Maubant et al., (2017). (A) Coseismic slip distribution of the Amatrice earthquake from Ragon et al., (2019) (B-C-E-F) Surface displacements predicted by four visco-elastic models on $24^{\text {th }}$ February 2017 using Relax software (Barbot \& Fialko, 2010). Mantle viscosity is fixed for all models at $10^{21}$ Pas. (D) Post-Norcia earthquake (30 ${ }^{\text {th }}$ October) cumulative displacement map (11 ${ }^{\text {th }}$ February 2017) observed by InSAR (uplift component). (VBFS: Mt Vettore - Mt Bove Fault System, A-C F: Amatrice-Campotosto Fault, OAS: Olevano-Antrodoco-Sibillini thrust) 


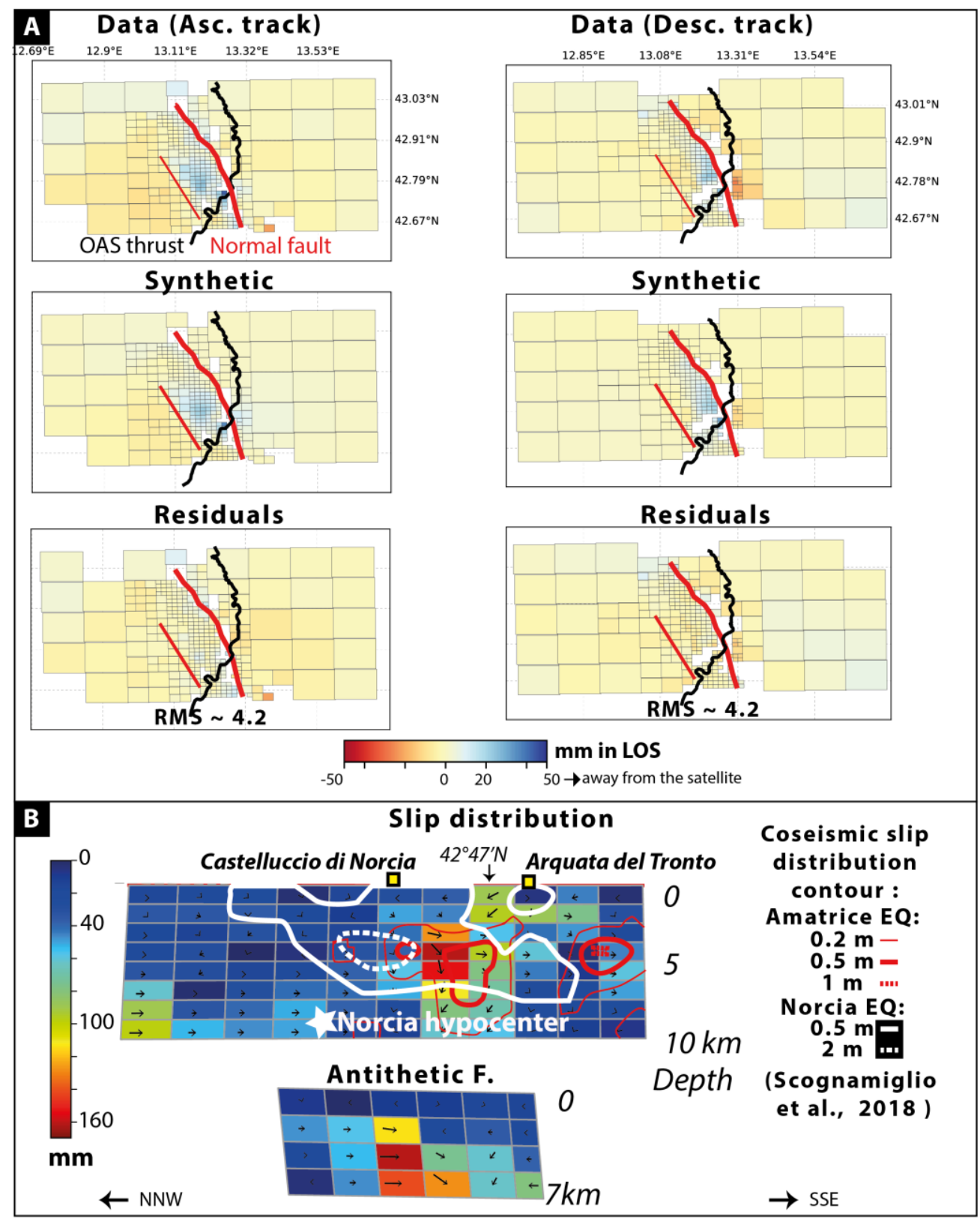

Figure 7: Result of afterslip inversion using the CSI software (see Supplementary text S3 for details). (A) Subsampled displacement maps for the ascending (left column) and descending (right column) tracks. Top row shows the input subsampled data, middle row shows the synthetic displacements predicted by the model, and bottom row shows the residuals (i.e. model - data). The modeled fault geometries used for the inversion are plotted in Figure 2-A. The input maps are the smoothed cumulative displacement maps on February $11^{\text {th }}$ (calculated in the ascending and descending post-30 ${ }^{\text {th }}$ October time-series). (B) Afterslip distribution inverted from the data on the main fault and the antithetic fault. Black arrows in patches show the rake. Our model has low resolution at depth (Figure S16). Coseismic slip distributions for 
632 the Amatrice and Norcia earthquakes (Scognamiglio et al., (2018) are superimposed in white 633 and red, respectively. Comparison with the Cheloni et al.,(2019) model in Figure S21 shows 634 similar patterns.

635

636 


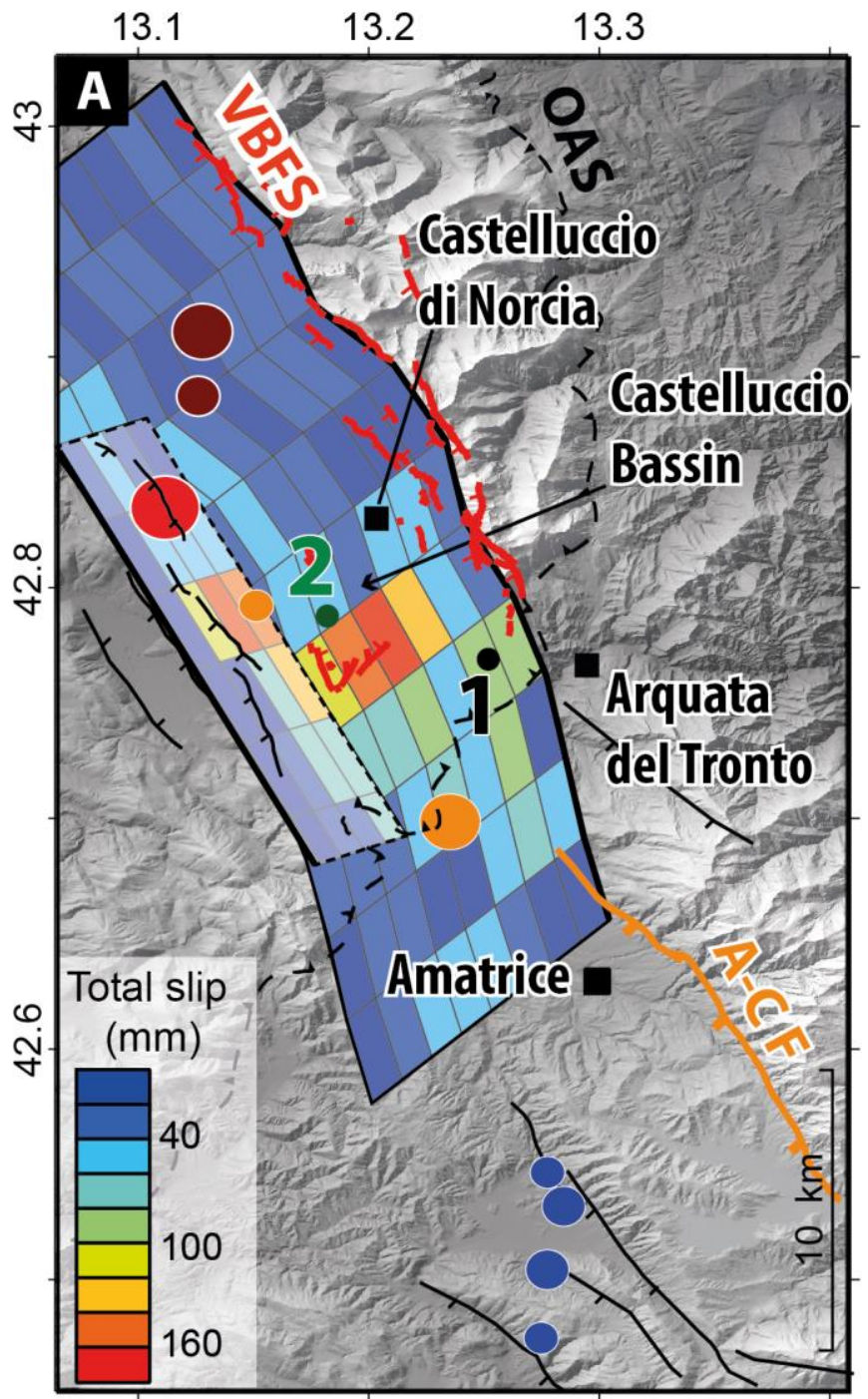

638

639 Figure 8: Afterslip distribution model plotted on mapview. The slip distribution is inverted from 640 the data on the main fault and the antithetic fault (see Figure 7). (VBFS: Mt Vettore - Mt Bove 641 Fault System, A-C F: Amatrice-Campotosto Fault). Circles are the main earthquakes of the 642 seismic sequence. 
645 We would like to thank the Editor, Associate Editor, Mong-Han Huang and two anonymous

646 reviewers for their constructive suggestions, which helped to improve the manuscript substantially. We

647 acknowledge the French Spatial Agency CNES (Centre National d'Etudes Spatiales) for funding this

648 study (Program THEIA and CNES post-doctorate fellowship for L.Pousse-Beltran). This work was also

649 funded through the TELLUS-ALEAS program from Institut des Sciences de I'Univers (INSU). CNES is

650 warmly acknowledged from providing us with the Pléaides satellite images through ISIS and

651 CEOS_seismic pilot (ESA) programs. Nicola D'Agostino was under an invited researcher position at Univ.

652 Grenoble Alpes - OSUG - ISTerre when most of the work was performed. Most of the computations

653 presented in this paper were performed using the Luke platform of the CIMENT infrastructure

654 (https://ciment.ujf-grenoble.fr), which is supported by the Rhône-Alpes region (grant CPER07_13

655 CIRA), the OSUG@2020 labex (reference ANR10 LABX56), and the Equip@Meso project (reference

656 ANR-10-EQPX-29-01) of the programme Investissements d'Avenir supervised by the Agence Nationale

657 pour la Recherche. Franck Thollard, Christophe Laurent, Erwan Pathier, Louise Maubant and Simon

658 Daout are warmly acknowledged for help and advice on NSBAS processing chain. We are also grateful

659 to Théa Ragon and Romain Jolivet for support and advice in slip distribution modelling, the CSI software

660 will be soon released online. We thank Louise Maubant and James Hollingsworth for sharing the Norcia

661 slip distribution model. Alberto Pizzi, Bruno Pace, Paolo Boncio and Irene Puliti are also warmly

662 acknowledged for fruitful discussions. The European Space Agency (ESA) Copernicus program has

663 provided free and high-quality SAR data from Sentinel-1A and 1B (ESA,

664 https://scihub.copernicus.eu) through the PEPS platform of CNES (Copernicus 2018 for Sentinel

665 data. We thank Simone Tarquini for the supply of $10 \mathrm{~m}$ resolution TINITALY DEM. The afterslip

666 distribution model will be provided in 10.5281/zenodo.3755127. Seismicity used for this research is

667 included in (Chiaraluce et al., 2017) and in http://cnt.rm.ingv.it/. The GNSS stations are downloaded

668 from http://geodesy.unr.edu/NGLStationPages/stations/ 
670

671

672

673

674

675

676

677

678

679

680

681

682

683

684

685

686

687

688

689

690

691

692

693

694

695

696

697

698

\section{References}

Albano, M., Barba, S., Solaro, G., Pepe, A., Christian, B., Moro, M., et al. (2017). Aftershocks, groundwater changes and postseismic ground displacements related to pore pressure gradients: Insights from the 2012 Emilia-Romagna earthquake. Journal of Geophysical Research: Solid Earth, 122(7), 5622-5638. https://doi.org/10.1002/2017JB014009

Albano, M., Barba, S., Saroli, M., Polcari, M., Bignami, C., Moro, M., et al. (2018). Aftershock rate and pore fluid diffusion: Insights from the Amatrice-Visso-Norcia (Italy) 2016 seismic sequence. Journal of Geophysical Research: Solid Earth, O(ja). https://doi.org/10.1029/2018JB015677

Amoruso, A., Crescentini, L., D’Anastasio, E., \& Martini, P. M. D. (2005). Clues of postseismic relaxation for the 1915 Fucino earthquake (central Italy) from modeling of leveling data. Geophysical Research Letters, 32(22). https://doi.org/10.1029/2005GL024139

Aoudia, A., Borghi, A., Riva, R., Barzaghi, R., Ambrosius, B. a. C., Sabadini, R., et al. (2003). Postseismic deformation following the 1997 Umbria-Marche (Italy) moderate normal faulting earthquakes. Geophysical Research Letters, 30(7). https://doi.org/10.1029/2002GL016339

Aslan, G., Lasserre, C., Cakir, Z., Ergintav, S., Özarpaci, S., Dogan, U., et al. (2019). Shallow Creep Along the 1999 Izmit Earthquake Rupture (Turkey) From GPS and High Temporal Resolution Interferometric Synthetic Aperture Radar Data (2011-2017). Journal of Geophysical Research: Solid Earth, 124(2), 2218-2236. https://doi.org/10.1029/2018JB017022

Avouac, J.-P. (2015). From Geodetic Imaging of Seismic and Aseismic Fault Slip to Dynamic Modeling of the Seismic Cycle. Annual Review of Earth and Planetary Sciences, 43(1), 233-271. https://doi.org/10.1146/annurev-earth-060614-105302

Barbot, S., \& Fialko, Y. (2010). A unified continuum representation of post-seismic relaxation mechanisms: semi-analytic models of afterslip, poroelastic rebound and viscoelastic flow: Semi-analytic models of postseismic transient. Geophysical Journal International, 182(3), 1124-1140. https://doi.org/10.1111/j.1365-246X.2010.04678.x 
Barnhart, W. D., Murray, J. R., Briggs, R. W., Gomez, F., Miles, C. P. J., Svarc, J., et al. (2016). Coseismic slip and early afterslip of the 2015 Illapel, Chile, earthquake: Implications for frictional heterogeneity and coastal uplift. Journal of Geophysical Research: Solid Earth, 121(8), 6172-6191. https://doi.org/10.1002/2016JB013124

Benedetti, L. (1999). Sismotectonique de l'Italie et des régions adjacentes: fragmentation du promontoire adiratique (PhD Thesis). Paris 7.

Blewitt, G., Hammond, W., \& Kreemer, C. (2018). Harnessing the GPS Data Explosion for Interdisciplinary Science. Eos, 99. https://doi.org/10.1029/2018EO104623

Boni, C. F., TARRAGONI, C., MARTARELLI, L., \& PIERDOMINICI, S. (2010). STUDIO IDROGEOLOGICO NEL SETTORE NORD-OCCIDENTALE DEI MONTI SIBILLINI: UN CONTRIBUTO ALLA CARTOGRAFIA IDROGEOLOGICA UFFICIALE. Italian Journal of Engineering Geology and Environment, 2, 16. https://doi.org/10.4408/IJEGE.201002.0-02

Brozzetti, F., Boncio, P., Cirillo, D., Ferrarini, F., Nardis, R. de, Testa, A., et al. (2019). HighResolution Field Mapping and Analysis of the August-October 2016 Coseismic Surface Faulting (Central Italy Earthquakes): Slip Distribution, Parameterization, and $\begin{array}{llll}\text { Comparison With } \quad \text { Global } & \text { Earthquakes. }\end{array}$ https://doi.org/10.1029/2018TC005305

Bürgmann, R. (2018). The geophysics, geology and mechanics of slow fault slip. Earth and Planetary Science Letters, 495, 112-134. https://doi.org/10.1016/j.epsl.2018.04.062

Calamita, F., Cello, G., Deiana, G., \& Paltrinieri, W. (1994). Structural styles, chronology rates of deformation, and time-space relationships in the Umbria-Marche thrust system (central Apennines, Italy). Tectonics, 13(4), 873-881. https://doi.org/10.1029/94TC00276

Calamita, F., Satolli, S., Scisciani, V., Esestime, P., \& Pace, P. (2011). Contrasting styles of fault reactivation in curved orogenic belts: Examples from the Central Apennines (Italy). Geological Society of America Bulletin, 123(5-6), 1097-1111. https://doi.org/10.1130/B30276.1 
Calamita, F., Satolli, S., \& Turtù, A. (2012). Analysis of thrust shear zones in curve-shaped belts: Deformation mode and timing of the Olevano-Antrodoco-Sibillini thrust (Central/Northern Apennines of Italy). Journal of Structural Geology, 44, 179-187. https://doi.org/10.1016/j.jsg.2012.07.007

Carafa, M. M. C., \& Bird, P. (2016). Improving deformation models by discounting transient signals in geodetic data: 2 . Geodetic data, stress directions, and long-term strain rates in Italy. Journal of Geophysical Research: Solid Earth, 121(7), 5557-5575. https://doi.org/10.1002/2016JB013038

Cavalié, O., Doin, M.-P., Lasserre, C., \& Briole, P. (2007). Ground motion measurement in the Lake Mead area, Nevada, by differential synthetic aperture radar interferometry time series analysis: Probing the lithosphere rheological structure. Journal of Geophysical Research: Solid Earth, 112(B3), n/a-n/a. https://doi.org/10.1029/2006JB004344

Cheloni, D., De Novellis, V., Albano, M., Antonioli, A., Anzidei, M., Atzori, S., et al. (2017). Geodetic model of the 2016 Central Italy earthquake sequence inferred from InSAR and GPS data. Geophysical Research Letters, 44(13), 2017 GL073580. https://doi.org/10.1002/2017GL073580

Cheloni, D., Falcucci, E., \& Gori, S. (2019). Half-graben rupture geometry of the 30 October 2016 MW 6.6 Mt. Vettore-Mt. Bove earthquake, central Italy. Journal of Geophysical Research: Solid Earth, O(ja). https://doi.org/10.1029/2018JB015851

Chen, K. H., \& Bürgmann, R. (2017). Creeping faults: Good news, bad news? Reviews of Geophysics, 55(2), 2017RG000565. https://doi.org/10.1002/2017RG000565

Chiarabba, C., Gori, P. D., Cattaneo, M., Spallarossa, D., \& Segou, M. (2018). Faults geometry and the role of fluids in the 2016-2017 Central Italy seismic sequence. Geophysical Research Letters, $O$ (ja). https://doi.org/10.1029/2018GL077485

Chiaraluce, L., Stefano, R. D., Tinti, E., Scognamiglio, L., Michele, M., Casarotti, E., et al. (2017). The 2016 Central Italy Seismic Sequence: A First Look at the Mainshocks, Aftershocks, and Source Models. Seismological Research Letters, 88(3), 757-771. https://doi.org/10.1785/0220160221 
Cirella, A., Pezzo, G., \& Piatanesi, A. (2018). Rupture Kinematics and Structural - Rheological Control of the 2016 Mw6.1 Amatrice (Central Italy) Earthquake from Joint Inversion of Seismic and Geodetic Data. Geophysical Research Letters, $O(j a)$. https://doi.org/10.1029/2018GL080894

Civico, R., Pucci, S., Villani, F., Pizzimenti, L., Martini, P. M. D., Nappi, R., \& Group, the O. E. W. (2018). Surface ruptures following the 30 October 2016 Mw 6.5 Norcia earthquake, central Italy. Journal of Maps, 14(2), 151-160. https://doi.org/10.1080/17445647.2018.1441756

D'Agostino, N. (2014). Complete seismic release of tectonic strain and earthquake recurrence in the Apennines (Italy). Geophysical Research Letters, 41(4), 1155-1162. https://doi.org/10.1002/2014GL059230

D’Agostino, N., Cheloni, D., Fornaro, G., Giuliani, R., \& Reale, D. (2012). Space-time distribution of afterslip following the 2009 L'Aquila earthquake. Journal of Geophysical Research: Solid Earth, 117, n/a-n/a. https://doi.org/10.1029/2011jb008523

Daout, S., Jolivet, R., Lasserre, C., Doin, M.-P., Barbot, S., Tapponnier, P., et al. (2016). Alongstrike variations of the partitioning of convergence across the Haiyuan fault system detected by InSAR. Geophysical Journal International, 205(1), 536-547.

Daout, S., Sudhaus, H., Kausch, T., Steinberg, A., \& Dini, B. (2019). Interseismic and Postseismic Shallow Creep of the North Qaidam Thrust Faults Detected with a Multitemporal InSAR Analysis. Journal of Geophysical Research: Solid Earth, 124(7), 7259-7279. https://doi.org/10.1029/2019JB017692

Devoti, R., D’Agostino, N., Serpelloni, E., Pietrantonio, G., Riguzzi, F., Avallone, A., et al. (2017). A Combined Velocity Field of the Mediterranean Region. Annals of Geophysics, 60(2). https://doi.org/10.4401/ag-7059

Di Domenica, A., Turtù, A., Satolli, S., \& Calamita, F. (2012). Relationships between thrusts and normal faults in curved belts: New insight in the inversion tectonics of the CentralNorthern Apennines (Italy). Journal of Structural Geology, 42, 104-117. https://doi.org/10.1016/j.jsg.2012.06.008 
Dieterich, J. H. (1979). Modeling of rock friction: 1. Experimental results and constitutive equations. Journal of Geophysical Research: Solid Earth, 84(B5), 2161-2168. https://doi.org/10.1029/JB084iB05p02161

Doin, M.-P., Lodge, F., Guillaso, S., Jolivet, R., Lasserre, C., Ducret, G., et al. (2011). Presentation of the small baseline NSBAS processing chain on a case example: the Etna deformation monitoring from 2003 to 2010 using ENVISAT data. In Proceedings of the Fringe symposium, Frascati, Italy, ESA SP-697.

Doin, M.-P., Twardzik, C., Ducret, G., Lasserre, C., Guillaso, S., \& Jianbao, S. (2015). InSAR measurement of the deformation around Siling Co Lake: Inferences on the lower crust viscosity in central Tibet. Journal of Geophysical Research: Solid Earth, 120(7), 52905310. https://doi.org/10.1002/2014JB011768

Elliott, J. R., Jolivet, R., González, P. J., Avouac, J.-P., Hollingsworth, J., Searle, M. P., \& Stevens, V. L. (2016). Himalayan megathrust geometry and relation to topography revealed by the Gorkha earthquake. Nature Geoscience, 9(2), 174-180. https://doi.org/10.1038/ngeo2623

Elliott, J. R., Walters, R. J., \& Wright, T. J. (2016). The role of space-based observation in understanding and responding to active tectonics and earthquakes. Nature Communications, 7, 13844. https://doi.org/10.1038/ncomms13844

Falcucci, E., Gori, S., Bignami, C., Pietrantonio, G., Melini, D., Moro, M., et al. (2018). The Campotosto seismic gap in between the 2009 and 2016-2017 seismic sequences of central Italy and the role of inherited lithospheric faults in regional seismotectonic settings. Tectonics, $O$ (ja). https://doi.org/10.1029/2017TC004844

Freed, A. M. (2007). Afterslip (and only afterslip) following the 2004 Parkfield, California, earthquake. Geophysical Research Letters, 34(6), L06312. https://doi.org/10.1029/2006GL029155

Freed, A. M., \& Bürgmann, R. (2004). Evidence of power-law flow in the Mojave desert mantle. Nature, 430(6999), 548-551. https://doi.org/10.1038/nature02784 
Galadini, F., \& Galli, P. (2000). Active Tectonics in the Central Apennines (Italy) -Input Data for Seismic Hazard Assessment. Natural Hazards, 22(3), 225-268. https://doi.org/10.1023/A:1008149531980

Grandin, R. (2009). L'apport de la géodésie spatiale dans la compréhension du processus de rifting magmatique : l'exemple de l'épisode en cours en Afar Ethiopien (2005-2009). Institut de physique du globe (Paris). Retrieved from http://www.theses.fr/2009GLOB0013

Grandin, R. (2015). Interferometric Processing of SLC Sentinel-1 TOPS Data. In FRINGE'15: Advances in the Science and Applications of SAR Interferometry and Sentinel-1 InSAR Workshop, Frascati, Italy, 23-27 March 2015. Frascati, Italy. https://doi.org/10.5270/Fringe2015.pp116

Grandin, R., Doin, M.-P., Bollinger, L., Pinel-Puysségur, B., Ducret, G., Jolivet, R., \& Sapkota, S. N. (2012). Long-term growth of the Himalaya inferred from interseismic InSAR measurement. Geology, 40(12), 1059-1062. https://doi.org/10.1130/G33154.1

Gualandi, A., Serpelloni, E., \& Belardinelli, M. E. (2014). Space-time evolution of crustal deformation related to the Mw 6.3, 2009 L'Aquila earthquake (central Italy) from principal component analysis inversion of GPS position time-series. Geophysical Journal International, 197(1), 174-191. https://doi.org/10.1093/gji/ggt522

Harris, R. A. (2017). Large earthquakes and creeping faults. Reviews of Geophysics, 55(1), 2016RG000539. https://doi.org/10.1002/2016RG000539

Hetland, E. A., \& Zhang, G. (2014). Effect of shear zones on post-seismic deformation with application to the $1997 \mathrm{Mw}$ 7.6 Manyi earthquake. Geophysical Journal International, 198(1), 259-269. https://doi.org/10.1093/gji/ggu127

Hirose, H., Asano, Y., Obara, K., Kimura, T., Matsuzawa, T., Tanaka, S., \& Maeda, T. (2010). Slow Earthquakes Linked Along Dip in the Nankai Subduction Zone. Science, 330(6010), 1502-1502. https://doi.org/10.1126/science.1197102

Huang, M.-H., Fielding, E. J., Liang, C., Milillo, P., Bekaert, D., Dreger, D., \& Salzer, J. (2017). Coseismic deformation and triggered landslides of the $2016 \mathrm{Mw} 6.2$ Amatrice 

https://doi.org/10.1002/2016GL071687

840 Hussain, E., Wright, T. J., Walters, R. J., Bekaert, D. P. S., Lloyd, R., \& Hooper, A. (2018). Constant strain accumulation rate between major earthquakes on the North Anatolian Fault. Nature Communications, 9(1), 1392. https://doi.org/10.1038/s41467-018-03739-2

Johnson, K. M. (2006). Frictional Properties on the San Andreas Fault near Parkfield, California,

Jolivet, R., Simons, M., Agram, P. S., Duputel, Z., \& Shen, Z.-K. (2015). Aseismic slip and Inferred from Models of Afterslip following the 2004 Earthquake. Bulletin of the Seismological Society of America, 96(4B), S321-S338.

850 seismogenic coupling along the central San Andreas Fault. Geophysical Research Letters, 42(2). https://doi.org/10.1002/2014GL062222

Kaneko, Y., Avouac, J.-P., \& Lapusta, N. (2010). Towards inferring earthquake patterns from geodetic observations of interseismic coupling. Nature Geoscience, 3(5), 363-369. https://doi.org/10.1038/ngeo843

King. (1986). Speculations on the geometry of the initiation and termination processes of earthquake rupture and its relation to morphology and geological structure. Pure and Applied Geophysics, 124, 19. https://doi.org/10.1007/BF00877216

King, \& Nabelek. (1985). Role of Fault Bends in the Initiation and Termination of Earthquake Rupture. Science, 228(4702), 984-987. https://doi.org/10.1126/science.228.4702.984

Laske, G., Masters, G., Ma, Z., \& Pasyanos, M. (2013). Update on CRUST1.0 - A 1-degree Global Model of Earth's Crust, 15, EGU2013-2658. Presented at the EGU General Assembly Conference Abstracts.

Liu, C., Zheng, Y., Xie, Z., \& Xiong, X. (2017). Rupture features of the 2016 Mw 6.2 Norcia earthquake and its possible relationship with strong seismic hazards. Geophysical Research Letters, 44(3), 1320-1328. https://doi.org/10.1002/2016GL071958

López-Quiroz, P., Doin, M.-P., Tupin, F., Briole, P., \& Nicolas, J.-M. (2009). Time series analysis of Mexico City subsidence constrained by radar interferometry. Journal of Applied Geophysics, 69(1), 1-15. https://doi.org/10.1016/j.jappgeo.2009.02.006 
867

868

869

870

871

872

873

Marone, C. J., Scholtz, C. H., \& Bilham, R. (1991). On the mechanics of earthquake afterslip. Journal of Geophysical Research: Solid Earth, 96(B5), 8441-8452. https://doi.org/10.1029/91JB00275

Maubant, L., Socquet, A., Hollingsworth, J., Pathier, E., \& Pousse-Beltrán, L. (2017). The Seismic Sequence of the Norcia Earthquake, Italy 2016, seen by geodesy. In Cargese, 2nd of October - 6th of October 2017. France.

Moré, J. J. (1978). The Levenberg-Marquardt algorithm: Implementation and theory. In G. A. Watson (Ed.), Numerical Analysis (pp. 105-116). Springer Berlin Heidelberg.

Nielsen, S. B., \& Knopoff, L. (1998). The equivalent strength of geometrical barriers to earthquakes. Journal of Geophysical Research: Solid Earth, 103(B5), 9953-9965. https://doi.org/10.1029/97JB03293

Noda, H., \& Lapusta, N. (2013). Stable creeping fault segments can become destructive as a result of dynamic weakening. Nature, 493(7433), 518-521. https://doi.org/10.1038/nature11703

Papadopoulos, G. A., Ganas, A., Agalos, A., Papageorgiou, A., Triantafyllou, I., Kontoes, C., et al. (2017). Earthquake Triggering Inferred from Rupture Histories, DInSAR Ground Deformation and Stress-Transfer Modelling: The Case of Central Italy During August 2016-January 2017. Pure and Applied Geophysics, 174(10), 3689-3711. https://doi.org/10.1007/s00024-017-1609-8

Pavlides, S., Chatzipetros, A., Papathanasiou, G., Georgiadis, G., Sboras, S., \& Valkaniotis, S. (2017). Ground deformation and fault modeling of the 2016 sequence (24 Aug. - 30 Oct.) in central Apennines (Central Italy). Bulletin of the Geological Society of Greece, 51(0), 76-112. https://doi.org/10.12681/bgsg.14334

Perfettini, H., \& Avouac, J.-P. (2004). Postseismic relaxation driven by brittle creep: A possible mechanism to reconcile geodetic measurements and the decay rate of aftershocks, application to the Chi-Chi earthquake, Taiwan. Journal of Geophysical Research: Solid Earth, 109(B2). https://doi.org/10.1029/2003JB002488 
Perfettini, H., Avouac, J.-P., Tavera, H., Kositsky, A., Nocquet, J.-M., Bondoux, F., et al. (2010). Seismic and aseismic slip on the Central Peru megathrust. Nature, 465(7294), 78-81. https://doi.org/10.1038/nature09062

Perouse, E., Benedetti, L., Fleury, J., Rizza, M., Puliti, I., Billant, J., et al. (2018). Coseismic Slip Vectors of 24 August and 30 October 2016 Earthquakes in Central Italy: Oblique Slip and Regional Kinematic Implications. Tectonics, 37(10), 3760-3781. https://doi.org/10.1029/2018TC005083

Petitta, M., Mastrorillo, L., Preziosi, E., Banzato, F., Barberio, M. D., Billi, A., et al. (2018). Watertable and discharge changes associated with the 2016-2017 seismic sequence in central Italy: hydrogeological data and a conceptual model for fractured carbonate aquifers. Hydrogeology Journal, 1-18. https://doi.org/10.1007/s10040-017-1717-7

Pinel-Puysségur, B., Michel, R., \& Avouac, J.-P. (2012). Multi-link InSAR time series: Enhancement of a wrapped interferometric database. IEEE Journal of Selected Topics in Applied Earth Observations and Remote Sensing, 5(3), 784-794. https://doi.org/10.1109/JSTARS.2012.2196758

Pino, N. A., Convertito, V., \& Madariaga, R. (2019). Clock advance and magnitude limitation through fault interaction: the case of the 2016 central Italy earthquake sequence. Scientific Reports, 9(1), 5005. https://doi.org/10.1038/s41598-019-41453-1

Pizzi, A., Di Domenica, A., Gallovič, F., Luzi, L., \& Puglia, R. (2017). Fault segmentation as constraint to the occurrence of the main shocks of the 2016 Central Italy seismic sequence. Tectonics, 2017TC004652. https://doi.org/10.1002/2017TC004652

Pluymakers, A. M. H., Niemeijer, A. R., \& Spiers, C. J. (2016). Frictional properties of simulated anhydrite-dolomite fault gouge and implications for seismogenic potential. Journal of Structural Geology, 84, 31-46. https://doi.org/10.1016/j.jsg.2015.11.008

Pollitz, F. F., Wicks, C., \& Thatcher, W. (2001). Mantle Flow Beneath a Continental Strike-Slip Fault: Postseismic Deformation After the 1999 Hector Mine Earthquake. Science, 293(5536), 1814-1818. https://doi.org/10.1126/science.1061361

Porreca, M., Minelli, G., Ercoli, M., Brobia, A., Mancinelli, P., Cruciani, F., et al. (2018). Seismic reflection profiles and subsurface geology of the area interested by the 2016-2017 

https://doi.org/10.1002/2017TC004915

925 Puliti, I., Pizzi, A., Benedetti, L., Domenica, A. D., \& Fleury, J. (2020). Comparing slip distribution of an active fault system at various timescales: insights for the evolution of the Mt. Vettore- Mt. Bove fault system in Central Apennines. Tectonics, $n / a(n / a)$, e2020TC006200. https://doi.org/10.1029/2020TC006200

Rousset, B., Campillo, M., Lasserre, C., Frank, W. B., Cotte, N., Walpersdorf, A., et al. (2017). A geodetic matched filter search for slow slip with application to the Mexico subduction zone: GEODETIC MATCHED FILTER FOR SLOW SLIP. Journal of Geophysical Research: Solid Earth, 122(12), 10,498-10,514. https://doi.org/10.1002/2017JB014448 
Ruina, A. (1983). Slip instability and state variable friction laws. Journal of Geophysical Research:

Solid

Earth,

88(B12),

10359-10370. https://doi.org/10.1029/JB088iB12p10359

953 Scholz, C. H. (1998). Earthquakes and friction laws. Nature, 391(6662), 37-42. https://doi.org/10.1038/34097

Scognamiglio, L., Tinti, E., Casarotti, E., Pucci, S., Villani, F., Cocco, M., et al. (2018). Complex fault geometry and rupture dynamics of the Mw 6.5, 2016, October 30th central Italy earthquake. Journal of Geophysical Research: Solid Earth. https://doi.org/10.1002/2018JB015603

Scuderi, M. M., \& Collettini, C. (2016). The role of fluid pressure in induced vs. triggered

Silverii, F., D’Agostino, N., Métois, M., Fiorillo, F., \& Ventafridda, G. (2016). Transient deformation of karst aquifers due to seasonal and multiyear groundwater variations observed by GPS in southern Apennines (Italy). Journal of Geophysical Research: Solid Earth, 121(11), 8315-8337. https://doi.org/10.1002/2016JB013361

Smeraglia, L., Billi, A., Carminati, E., Cavallo, A., \& Doglioni, C. (2017). Field- to nano-scale evidence for weakening mechanisms along the fault of the 2016 Amatrice and Norcia earthquakes, Italy. Tectonophysics. https://doi.org/10.1016/j.tecto.2017.05.014

Tarantola, A. (2005). Inverse Problem Theory and Methods for Model Parameter Estimation. Society for Industrial and Applied Mathematics. https://doi.org/10.1137/1.9780898717921

Tesson, J., Pace, B., Benedetti, L., Visini, F., Delli Rocioli, M., Arnold, M., et al. (2016). Seismic slip history of the Pizzalto fault (central Apennines, Italy) using in situ-produced $36 \mathrm{Cl}$ cosmic ray exposure dating and rare earth element concentrations. Journal of Geophysical Research: Solid Earth, 121(3), 2015JB012565. https://doi.org/10.1002/2015JB012565

Thomas, M. Y., Avouac, J.-P., \& Lapusta, N. (2017). Rate-and-state friction properties of the Longitudinal Valley Fault from kinematic and dynamic modeling of seismic and aseismic 
slip. Journal of Geophysical Research: Solid Earth, $2016 J \mathrm{~J} 013615$. https://doi.org/10.1002/2016JB013615

981 Thompson, G. A., \& Parsons, T. (2016). Vertical deformation associated with normal fault systems evolved over coseismic, postseismic, and multiseismic periods. Journal of Geophysical Research: Solid Earth, 121(3), 2153-2173.

985 Tung, S., \& Masterlark, T. (2018). Delayed poroelastic triggering of the 2016 October Visso 986 earthquake by the August Amatrice earthquake, Italy. Geophysical Research Letters. https://doi.org/10.1002/2017GL076453

Walters, R. J., Gregory, L. C., Wedmore, L. N. J., Craig, T. J., McCaffrey, K., Wilkinson, M., et al. (2018). Dual control of fault intersections on stop-start rupture in the 2016 Central Italy seismic sequence. Earth and Planetary Science Letters, 500, 1-14. https://doi.org/10.1016/j.epsl.2018.07.043 
Wang, L., Gao, H., Feng, G., \& Xu, W. (2018). Source parameters and triggering links of the earthquake sequence in central Italy from 2009 to 2016 analyzed with GPS and InSAR data. Tectonophysics. https://doi.org/10.1016/j.tecto.2018.07.013

Wesnousky, S. G. (1988). Seismological and structural evolution of strike-slip faults. Nature, 335(6188), 340. https://doi.org/10.1038/335340a0

Xu, G., Xu, C., Wen, Y., \& Jiang, G. (2017). Source Parameters of the 2016-2017 Central Italy Earthquake Sequence from the Sentinel-1, ALOS-2 and GPS Data. Remote Sensing, 9(11), 1182. https://doi.org/10.3390/rs9111182

Zhao, B., Bürgmann, R., Wang, D., Tan, K., Du, R., \& Zhang, R. (2017). Dominant Controls of Downdip Afterslip and Viscous Relaxation on the Postseismic Displacements Following the Mw7.9 Gorkha, Nepal, Earthquake. Journal of Geophysical Research: Solid Earth, 122(10), 8376-8401. https://doi.org/10.1002/2017JB014366

Zhou, Y., Thomas, M. Y., Parsons, B., \& Walker, R. T. (2018). Time-dependent postseismic slip following the $1978 \mathrm{Mw}$ 7.3 Tabas-e-Golshan, Iran earthquake revealed by over 20 years of ESA InSAR observations. Earth and Planetary Science Letters, 483, 64-75. https://doi.org/10.1016/j.epsl.2017.12.005

\section{References for supplementary materials}

Blewitt, G, WC Hammond, and C Kreemer. 2018. "Harnessing the GPS Data Explosion for Interdisciplinary Science." Eos 99. https://doi.org/10.1029/2018EO104623.

Boni, CARLO FELICE, CLAUDIA TARRAGONI, LUCIO MARTARELLI, and SIMONA PIERDOMINICI. 2010. "STUDIO IDROGEOLOGICO NEL SETTORE NORD-OCCIDENTALE DEI MONTI SIBILLINI: UN CONTRIBUTO ALLA CARTOGRAFIA IDROGEOLOGICA UFFICIALE." Italian Journal of Engineering Geology and Environment 2: 16. https://doi.org/10.4408/IJEGE.2010-02.0-02.

Cheloni, D., E. Falcucci, and S. Gori. 2019. "Half-Graben Rupture Geometry of the 30 October 2016 MW 6.6 Mt. Vettore-Mt. Bove Earthquake, Central Italy." Journal of Geophysical Research: Solid Earth 0 (ja). https://doi.org/10.1029/2018JB015851. 
Chiaraluce, L., R. Di Stefano, E. Tinti, L. Scognamiglio, M. Michele, E. Casarotti, M. Cattaneo, et al. 2017. "The 2016 Central Italy Seismic Sequence: A First Look at the Mainshocks, Aftershocks, and Source Models." Seismological Research Letters 88 (3): 757-71. https://doi.org/10.1785/0220160221.

Chiles, Jean-Paul, and Pierre Delfiner. 2009. Geostatistics: Modeling Spatial Uncertainty. Vol. 497. John Wiley \& Sons.

Grandin, R. 2009. L'Apport de La Géodésie Spatiale Dans La Compréhension Du Processus de Rifting Magmatique : L'exemple de l'épisode En Cours En Afar Ethiopien (2005-2009). Institut de physique du globe (Paris). http://www.theses.fr/2009GLOB0013.

Hansen, P. 1992. "Analysis of Discrete III-Posed Problems by Means of the L-Curve." SIAM Review 34 (4): 561-80. https://doi.org/10.1137/1034115.

Improta, Luigi, Diana Latorre, Lucia Margheriti, Anna Nardi, Alessandro Marchetti, Anna Maria Lombardi, Barbara Castello, et al. 2019. “Multi-Segment Rupture of the 2016 AmatriceVisso-Norcia Seismic Sequence (Central Italy) Constrained by the First High-Quality Catalog of Early Aftershocks." Scientific Reports 9 (1): 6921. https://doi.org/10.1038/s41598-019-43393-2.

Jolivet, R., C. Lasserre, M.-P. Doin, S. Guillaso, G. Peltzer, R. Dailu, J. Sun, Z.-K. Shen, and X. Xu. 2012. "Shallow Creep on the Haiyuan Fault (Gansu, China) Revealed by SAR Interferometry." Journal of Geophysical Research: Solid Earth 117 (B6): B06401. https://doi.org/10.1029/2011JB008732.

Jolivet, R., M. Simons, P. S. Agram, Z. Duputel, and Z.-K. Shen. 2015. “Aseismic Slip and Seismogenic Coupling along the Central San Andreas Fault." Geophysical Research Letters 42 (2). https://doi.org/10.1002/2014GL062222.

Lohman, Rowena B., and Mark Simons. 2005. "Some Thoughts on the Use of InSAR Data to Constrain Models of Surface Deformation: Noise Structure and Data Downsampling." Geochemistry, Geophysics, Geosystems $6 \quad$ (1): Q01007. https://doi.org/10.1029/2004GC000841.

Maubant, Louise, Anne Socquet, James Hollingsworth, Erwan Pathier, and Pousse Lea. 2017. "The Seismic Sequence of the Norcia Earthquake, Italy 2016, Seen by Geodesy." In 
Colloque G2 2017 Géodésie - Rhéologie, 13-15 Nov. 2017 Nice. France. https://g22017.sciencesconf.org/program.

1065

1066

1067

1068

1069

1070

1071

1072

1073

1074

1075

1076

1077

1078

1079

1080

1081

1082

1083

1084

1085

1086

1087

1088

1089

1090

Petitta, Marco, Lucia Mastrorillo, Elisabetta Preziosi, Francesca Banzato, Marino Domenico Barberio, Andrea Billi, Costanza Cambi, et al. 2018. "Water-Table and Discharge Changes Associated with the 2016-2017 Seismic Sequence in Central Italy: Hydrogeological Data and a Conceptual Model for Fractured Carbonate Aquifers." Hydrogeology Journal, January, 1-18. https://doi.org/10.1007/s10040-017-1717-7.

Pierantoni, Pietro, Giovanni Deiana, and Sandro Galdenzi. 2013. "Stratigraphic and Structural Features of the Sibillini Mountains (Umbria-Marche Apennines, Italy)." Italian Journal of Geosciences 132 (3): 497-520. https://doi.org/10.3301/IJG.2013.08.

Puliti, I., A. Pizzi, L. Benedetti, A. Di Domenica, and J. Fleury. 2020. “Comparing Slip Distribution of an Active Fault System at Various Timescales: Insights for the Evolution of the Mt. Vettore- Mt. Bove Fault System in Central Apennines." Tectonics n/a (n/a): e2020TC006200. https://doi.org/10.1029/2020TC006200.

Radiguet, M., F. Cotton, M. Vergnolle, M. Campillo, B. Valette, V. Kostoglodov, and N. Cotte. 2011. "Spatial and Temporal Evolution of a Long Term Slow Slip Event: The 2006 Guerrero Slow Slip Event." Geophysical Journal International 184 (2): 816-28. https://doi.org/10.1111/j.1365-246X.2010.04866.x.

Ragon, Théa, Anthony Sladen, and Mark Simons. 2019. "Accounting for Uncertain Fault Geometry in Earthquake Source Inversions - II: Application to the Mw 6.2 Amatrice Earthquake, Central Italy." Geophysical Journal International. https://doi.org/10.1093/gji/ggz180.

Scognamiglio, L., E. Tinti, E. Casarotti, S. Pucci, F. Villani, M. Cocco, F. Magnoni, A. Michelini, and D. Dreger. 2018. “Complex Fault Geometry and Rupture Dynamics of the Mw 6.5, 2016, October 30th Central Italy Earthquake." Journal of Geophysical Research: Solid Earth. https://doi.org/10.1002/2018JB015603.

Sudhaus, Henriette, and Sigurjón Jonsson. 2009. "Improved Source Modelling through Combined Use of InSAR and GPS under Consideration of Correlated Data Errors: 
Application to the June 2000 Kleifarvatn Earthquake, Iceland." Geophysical Journal International 176 (2): 389-404. https://doi.org/10.1111/j.1365-246X.2008.03989.x.

1093 Tarantola, Albert. 2005. Inverse Problem Theory and Methods for Model Parameter Estimation. 1094 Society for Industrial and

Applied

Mathematics. https://doi.org/10.1137/1.9780898717921.

Tarantola, Albert, and Bernard Valette. 1982. “Generalized Nonlinear Inverse Problems Solved 1097 Using the Least Squares Criterion." Reviews of Geophysics 20 (2): 219. https://doi.org/10.1029/RG020i002p00219. (March): 141-46. https://doi.org/10.3301/ROL.2019.25.

Villani, Fabio, Riccardo Civico, Stefano Pucci, Luca Pizzimenti, Rosa Nappi, Paolo Marco De Martini, the Open EMERGEO Working Group, et al. 2018. “A Database of the Coseismic Effects Following the 30 October 2016 Norcia Earthquake in Central Italy." Scientific Data 5 (March): 180049. https://doi.org/10.1038/sdata.2018.49.

Wackernagel, Hans. 2003. Multivariate Geostatistics: An Introduction with Applications. 3rd ed. Berlin Heidelberg: Springer-Verlag. https://doi.org/10.1007/978-3-662-05294-5.

Wright, Tim J., Barry E. Parsons, and Zhong Lu. 2004. "Toward Mapping Surface Deformation in Three Dimensions Using InSAR." Geophysical Research Letters 31 (1). https://doi.org/10.1029/2003GL018827. 